Synthesis, spectroscopic characterization, crystal structure, Hirshfeld surface analysis and antimicrobial activities of two triazole Schiff bases and their silver complexes

Peer-reviewed author version

Bouhidel, Zakaria; Cherouana, Aouatef; Durand, Pierrick; Doudouh, Abdelatif; MORINI, Filippo; Guillot, Benoit \& Dahaoui, Slimane (2018) Synthesis, spectroscopic characterization, crystal structure, Hirshfeld surface analysis and antimicrobial activities of two triazole Schiff bases and their silver complexes. In: INORGANICA CHIMICA ACTA, 482, p. 34-47.

DOI: 10.1016/j.ica.2018.05.028

Handle: http://hdl.handle.net/1942/26092 


\section{Accepted Manuscript}

Research paper

Synthesis, spectroscopic characterization, crystal structure, Hirshfeld surface analysis and antimicrobial activities of two triazole Schiff bases and their silver complexes

Zakaria Bouhidel, Aouatef Cherouana, Pierrick Durand, Abdelatif Doudouh, Filippo Morini, Benoit Guillot, Slimane Dahaoui

PII:

S0020-1693(17)31761-9

DOI: https://doi.org/10.1016/j.ica.2018.05.028

Reference:

ICA 18279

To appear in:

Inorganica Chimica Acta

Received Date:

15 November 2017

Revised Date:

8 April 2018

Accepted Date:

21 May 2018

Please cite this article as: Z. Bouhidel, A. Cherouana, P. Durand, A. Doudouh, F. Morini, B. Guillot, S. Dahaoui, Synthesis, spectroscopic characterization, crystal structure, Hirshfeld surface analysis and antimicrobial activities of two triazole Schiff bases and their silver complexes, Inorganica Chimica Acta (2018), doi: https://doi.org/ 10.1016/j.ica.2018.05.028

This is a PDF file of an unedited manuscript that has been accepted for publication. As a service to our customers we are providing this early version of the manuscript. The manuscript will undergo copyediting, typesetting, and review of the resulting proof before it is published in its final form. Please note that during the production process errors may be discovered which could affect the content, and all legal disclaimers that apply to the journal pertain. 


\title{
Synthesis, spectroscopic characterization, crystal structure, Hirshfeld surface analysis and antimicrobial activities of two triazole Schiff bases and their silver complexes
}

Zakaria Bouhidel ${ }^{\mathrm{a}}$, Aouatef Cherouana ${ }^{\mathrm{a}}$, Pierrick Durand ${ }^{\mathrm{b}}$, Abdelatif Doudouh ${ }^{\mathrm{b}}$, Filippo Morini $^{\mathrm{b}, \mathrm{c}}$, Benoit Guillot ${ }^{\mathrm{b}}$ and Slimane Dahaoui ${ }^{\mathrm{b} *}$,

${ }^{a}$ Unité de Recherche de Chimie de l'Environnement et Moléculaire Structurale (CHEMS), Département de Chimie, Université des frères Mentouri-Constantine 1, 25000 Constantine, Algeria.

${ }^{\mathrm{b}} \mathrm{CRM}^{2}$ (UMR UL-CNRS 7036). Faculté des Sciences et Technologies, Université de Lorraine. BP 70239, Boulevard des Aiguillettes. 54506 Vandoeuvre-lès-Nancy CEDEX.

${ }^{\mathrm{c}}$ Center of Molecular and Materials Modelling, Hasselt University, Agoralaan Gebouw D, B3590 Diepenbeek, Belgium.

\begin{abstract}
The present work describes the synthesis, structural characterization, Hirshfeld analysis, and antibacterial assays of two hydroxy Schiff bases with triazole moiety: $N$-[(E)-(3hydroxy)methylidene]-4H-1-2-4 triazol-4-amine (L1) and $N$-[(E)-(2,4dihydroxy)methylidene]-4H-1-2-4 triazol-4-amine (L2). The interaction of these two Schiff bases with $\mathrm{AgNO}_{3}$ leads to $\mathrm{Ag}(\mathrm{I})$ dimer $[\mathbf{A g}(\mathbf{L 1})]\left(\mathbf{N O}_{\mathbf{3}}\right)$ in the case of the first ligand (L1) and polymer $[\mathrm{Ag}(\mathbf{L} 2)]_{\mathbf{n}}\left(\mathrm{NO}_{3}\right)_{\mathbf{n}}\left(\mathrm{H}_{\mathbf{2}} \mathrm{O}\right)$ for $(\mathbf{L 2})$. Crystal structure determination and Hirshfeld analysis reveal the presence of two important hydrogen bond interactions in the four compounds, $\mathrm{O} \ldots \mathrm{H}$ and $\mathrm{H} \ldots \mathrm{N}$, involving nitrogen atoms of triazole ring. Contribution of these two types of hydrogen bonds evolves inversely from (L1) which contains one $-\mathrm{OH}$, to (L2) containing two $-\mathrm{OH}$, then to $[\mathbf{A g}(\mathbf{L 1})]\left(\mathbf{N O}_{3}\right)$ dimer and finally to $[\mathbf{A g}(\mathbf{L 2})]_{\mathbf{n}}\left(\mathbf{N O}_{\mathbf{3}}\right)_{\mathbf{n}}\left(\mathbf{H}_{\mathbf{2}} \mathbf{O}\right)$ polymer. Indeed, we observed an increase of the percentage to the Hirshfeld surfaces of O...H contribution from (L1) to $[\operatorname{Ag}(\mathbf{L 2})]_{\mathbf{n}}\left(\mathbf{N O}_{3}\right)_{\mathbf{n}}\left(\mathbf{H}_{2} \mathbf{O}\right)$ passing by $(\mathbf{L 2})$ and $[\operatorname{Ag}(\mathbf{L 1})]\left(\mathbf{N O}_{3}\right)$, while the percentage of N...H decrease in the same way. Antibacterial activity of the free ligands (L1), (L2) and their silver complexes $[\mathbf{A g}(\mathbf{L 1})]\left(\mathbf{N O}_{3}\right)$ and $[\operatorname{Ag}(\mathbf{L 2})]_{\mathbf{n}}\left(\mathbf{N O}_{3}\right)_{\mathbf{n}}\left(\mathbf{H}_{\mathbf{2}} \mathbf{O}\right)$ were evaluated against four Gram-negative (E. coli, Salmonella typhimurium, Klebsiella
\end{abstract}


pneumoniae and serratia marcescens) and two Gram-positive (Staphylococcus aureus, streptococcus) bacteria strains, using the standard antibiotics, Colistin, Fosfomycin, Gentamycin, Erythromycin, Rifampicin, Amikacin, Ofloxacin and Amoxicillin as positive controls. $\mathrm{AgNO}_{3}$ salt was also used as second control test. The results of this evaluation reveal that, while the two Schiff bases inhibit the growth of the Serratia Marcescens bacterium only, the two $\mathrm{Ag}(\mathrm{I})$ complexes are active for all bacteria, with activities comparable to the ones of silver nitrate. However, $[\mathbf{A g}(\mathbf{L 2})]_{\mathbf{n}}\left(\mathbf{N O}_{3}\right)_{\mathbf{n}}\left(\mathbf{H}_{\mathbf{2}} \mathbf{O}\right)$ complex appears significantly more efficient than the $\mathrm{AgNO}_{3}$ salt against Klebsiella Pneumoniae.

\section{Keywords}

Schiff bases; silver complexes; hydrogen bonding; Hirshfeld surfaces; antimicrobial activity

\section{Introduction}

Schiff bases i.e. $\mathrm{R} 2 \mathrm{C}=\mathrm{NR}^{\prime}\left(\mathrm{R}\right.$ and $\left.\mathrm{R}^{\prime} \neq \mathrm{H}\right)$, are an important class of organic compounds reported for the first time in 1864 by Hugo Schiff [1]. This family of compounds is used as starting materials in the synthesis of important drugs, such as antibiotics and antitumor substances [2-4]. A number of these bases have been reported to possess antioxidant, [5-9] anticonvulscent, [10] analgesic, [11] antituberclotic, [12] and diuretic [13] activities. Schiff bases have often been used as chelating ligands in the field of coordination chemistry for obtaining metal-based supramolecular assemblies, with a large number of potential applications such as catalysis, [14-15] photochemistry, [16] luminescence, [17] sensing, [18] magnetism, [19-20] gas storage, [21-23] gas purification, [24-25] and medicine [26-30].

Our interests have been in the synthesis, the characterization and the biological properties of heterocyclic Schiff bases and their Ag(I) complexes, where heterocycles are chosen as 1-2-4 triazole groups. Triazole moieties are indeed known as important polar pharmacophore able to act either as hydrogen bond donor or acceptor, and thus ready to interact with a variety of partners in biological systems. Triazole heterocyclic rings are thus considered as pharmacologically important scaffolds and are indeed used in many drugs associated to diverse biological activities [31, 32]. On the other hand, ionic silver is known for its antimicrobial properties for many centuries. Even if the precise mechanisms by which it is able to inhibit bacterial growth is still studied nowadays, it is commonly admitted that silver can kill bacteria by entering cells through impairment of enzymes binding $\operatorname{Ag}(\mathrm{I})$ ions on the surface of cell wall. Once inside the cell, proposed mechanisms range from the deactivation or 
the denaturation of essential enzymes by interaction between silver and sulfhydryl-containing molecules, to DNA denaturation by intercalation between base pairs. In any case, these mechanisms lead to a deep disruption of the cell metabolism and, finally, to cell death [33, 34]. Despite the historical knowledge of the antimicrobial properties of silver ions, the discovery and the development of antibiotics significantly reduced the search of new silverbased bactericidal agents and, overall, the use of silver in medicine. Nowadays the use of silver in medicine is in practice limited to burns treatment with silver sulfadiazine and wound management, for instance using dressings or medicinal devices coated with silver nanoparticles [35]. However, the emergence of antibiotic resistant bacteria strains and of multidrug-resistant organisms quite recently changed the situation and prompted the search of new antimicrobial drugs relying on the well-known properties of silver, such as silver coordination compounds. For instance, the literature is abundant concerning the development of silver complexes with $\mathrm{N}$-heterocycles (including triazoles), or N-heterocyclic carbenes [36], and the evaluation of their antibiotic properties. In addition to the evaluation of biological activities of our triazole substituted Schiff bases and their $\mathrm{Ag}(\mathrm{I})$ complexes, this study can be a plus for the construction of metal-organic frameworks (MOFs) with novel topology and for the crystal engineering of molecular architectures organized by coordination bonds and supramolecular contacts (such as hydrogen bonding, $\pi-\pi$ interactions). Indeed, $\operatorname{Ag}(\mathrm{I})$ is a favourable building block for constructing MOFs because of its flexible coordination numbers and weak metal-metal or metal-ligand interactions [37-38].

\section{Experimental}

\subsection{Reagents and measurements}

All reagents were commercially available, purchased from Sigma-Aldrich, and used without further purification. The IR spectra were recorded on a Nicolet 5700 FT-IR Thermo Scientific spectrophotometer using powder in mixed $\mathrm{KBr}$ pellets in the range of $400-4000 \mathrm{~cm}^{-1}$. The UV-Vis spectra were recorded at room temperature in the range of $100-900 \mathrm{~nm}$, on a Cary 4000 Varian UV-Visible spectrophotometer by dissolving the compounds in DMSO.

\subsection{Procedure of synthesis of the two Schiff bases and their silver complexes}

\subsubsection{Synthesis of $N$-[(E)-(3-hydroxyphenyl)methylidene]-4H-1-2-4 triazol-4-amine.}

\section{(L1):}

3-Hydroxybenzaldehyde $(0.244 \mathrm{~g}, 2 \mathrm{mmol})$, was added to an ethanolic solution (15 ml) of 4amino-4H-1,2,4-triazole $(0.161 \mathrm{~g}, 2 \mathrm{mmol})$ containing few drops of glacial acetic acid. The reaction mixture was stirred for $6 \mathrm{~h}$ under reflux at $75^{\circ}$. The resulting yellow solution was 
cooled in an ice bath. The crystalline powder obtained was filtered off, washed with ethanol and dried under vacuum. Pure colourless crystals for (L1) diffraction were obtained by recrystallization in acetonitrile/ $\mathrm{H}_{2} \mathrm{O} .{ }^{1} \mathrm{H} \mathrm{NMR}(250 \mathrm{MHz}$, [D6] DMSO, 300K): $\delta=9.04(2 \mathrm{H}$, s, $\left.\mathrm{H}_{1}, \mathrm{H}_{2}\right), 8.85\left(1 \mathrm{H}, \mathrm{s}, \mathrm{H}_{3}\right), 7.36\left(1 \mathrm{H}, \mathrm{m}, \mathrm{H}_{8}\right), 7.31\left(1 \mathrm{H}, \mathrm{m}, \mathrm{H}_{5}\right), 7.26\left(1 \mathrm{H}, \mathrm{m}, \mathrm{H}_{7}\right), 6.89(1 \mathrm{H}$, m, H9) ppm. ${ }^{13} \mathrm{C}$ NMR (250 MHz, [D6] DMSO, 300K) $\delta=159.76\left(\mathrm{C}_{6}\right), 158.27\left(\mathrm{C}_{3}\right), 140.09$ $\left(\mathrm{C}_{1}-\mathrm{C}_{2}\right), 134.00\left(\mathrm{C}_{8}\right), 131.50\left(\mathrm{C}_{9}\right), 121.69\left(\mathrm{C}_{5}\right), 120.83\left(\mathrm{C}_{7}\right), 115.07\left(\mathrm{C}_{4}\right)$ ppm. (supp.1). $\mathrm{C}_{9} \mathrm{H}_{8} \mathrm{~N}_{4} \mathrm{O}$ (188.19): calcd. C 57.44, H 4.28, N 29.77, O 8.50; found C 57.54, H 4.35, N 29.90, O 8.55.

\subsubsection{Synthesis of $N$-[(E)-(2,4-dihydroxyphenyl)methylidene]-4H-1-2-4 triazol-4-amine.} (L2) :

The pure crystals of second Schiff base (L2) was synthesized by the same procedure used for (L1). However, in this case, we use 2,4-dihydroxybenzaldehyde $(0.276 \mathrm{~g}, 2 \mathrm{mmol})$ instead of 3-hydroxybenzaldehyde. ${ }^{1} \mathrm{H}$ NMR (250 MHz, [D6] DMSO, $\left.300 \mathrm{~K}\right): \delta=8.98\left(2 \mathrm{H}, \mathrm{s}, \mathrm{H}_{1}, \mathrm{H}_{2}\right)$, $8.89\left(1 \mathrm{H}, \mathrm{s}, \mathrm{H}_{3}\right), 7.56(1 \mathrm{H}, \mathrm{d}, j=8.6 \mathrm{~Hz}, \mathrm{H} 9), 6.41\left(1 \mathrm{H}, \mathrm{dd}, \mathrm{j}=8.6 \mathrm{~Hz}, 2.0 \mathrm{~Hz}, \mathrm{H}_{8}\right), 6.34(1 \mathrm{H}, \mathrm{d}$, $\left.\mathrm{j}=2.0 \mathrm{~Hz}, \mathrm{H}_{6}\right) \mathrm{ppm} .{ }^{13} \mathrm{C} \mathrm{NMR}(250 \mathrm{MHz},[\mathrm{D} 6] \mathrm{DMSO}, 300 \mathrm{~K}) \delta=163.80\left(\mathrm{C}_{5}\right), 161.12\left(\mathrm{C}_{7}\right)$, $158.43\left(\mathrm{C}_{3}\right), 139.90\left(\mathrm{C}_{1}-\mathrm{C}_{2}\right), 132.37\left(\mathrm{C}_{9}\right), 110.57\left(\mathrm{C}_{6}\right), 109.75(\mathrm{C} 8), 103.57\left(\mathrm{C}_{4}\right) \mathrm{ppm}$. (supp.2). $\mathrm{C}_{9} \mathrm{H}_{8} \mathrm{~N}_{4} \mathrm{O}_{2}$ (188.19): calcd. C 52.89, H 3.92, N 27.43, O 15.67; found C 53.00, H 3.99, N 27.44, O 15.80.

\subsubsection{Synthesis of $[\mathrm{Ag}(\mathrm{L1})]\left(\mathrm{NO}_{3}\right)$ and $[\mathrm{Ag}(\mathrm{L2})]_{\mathbf{n}}\left(\mathrm{NO}_{3}\right)_{\mathbf{n}}\left(\mathrm{H}_{2} \mathrm{O}\right)$ :}

Complexes $[\mathrm{Ag}(\mathrm{L1})]\left(\mathrm{NO}_{3}\right)$ and $[\mathrm{Ag}(\mathrm{L2})]\left(\mathrm{NO}_{3}\right)\left(\mathrm{H}_{2} \mathrm{O}\right)$ were prepared by the reaction of $(\mathrm{L1})$ and (L2) respectively with $\mathrm{AgNO}_{3}(0.3: 0.3 \mathrm{mmol})$ in $14 \mathrm{ml}$ of $\mathrm{H}_{2} \mathrm{O} / \mathrm{CH}_{3} \mathrm{CN}$ (1:1) solution. After stirring for about $30 \mathrm{~min}$ at $50{ }^{\circ} \mathrm{C}$, the resulting solutions were filtered. Colourless single crystals suitable for X-ray diffraction were obtained by slow evaporation of the two solutions after few days. For $[\mathbf{A g}(\mathbf{L 1})]\left(\mathbf{N O}_{3}\right): \mathrm{AgC}_{18} \mathrm{H}_{16} \mathrm{~N}_{9} \mathrm{O}_{5}$ (546.27): $\mathrm{Ag} 19.75 \mathrm{C} 39.54, \mathrm{H}$ 2.93, N 23.06, O 14.64; found Ag 19.90 C 39.54, H 3.05, N 23.09, O 14.70. For [Ag(L2) ](NO $\left.\mathbf{N}_{3}\right)\left(\mathbf{H}_{2} \mathbf{O}\right): \mathrm{AgC}_{9} \mathrm{H}_{10} \mathrm{~N}_{5} \mathrm{O}_{6}$ (392.09): $\mathrm{Ag} 27.51 \mathrm{C} 27.54, \mathrm{H} 2.55, \mathrm{~N} 17.85$, O 24.48; found Ag 27.60 C 27.56, H 2.80, N 17.95, O 24.67.

\subsection{X-ray crystallography}

A suitable crystal of each compound was glued to a glass fibber mounted on dual source supernova with the large area Atlas CCD detector. Diffraction data were collected using the $\mathrm{Mo}-\mathrm{K} \alpha$ radiation at $100 \mathrm{~K}$. Correction for Lorentz-polarization effect, peak integration and 
reduction were carried out with CrysAlisPro package [39]. The structures were solved by direct methods and refined by full-matrix least squares method using SHELX programs [40]. All non-hydrogen atoms are placed appropriately and refined anisotropically. All $\mathrm{H}$ atoms were located in difference electron-density maps and were treated as riding on their parent atoms, with $\mathrm{C}-\mathrm{H}=0.93 \AA, \mathrm{N}-\mathrm{H}=0.85 \AA, \mathrm{O}-\mathrm{H}=0.84 \AA$ and $\mathrm{U}_{\mathrm{iso}}(\mathrm{H})=-1.2 \mathrm{U}_{\text {eq }}(\mathrm{X})(\mathrm{X}=\mathrm{C}$ and $\mathrm{N})$ and $-1.5 \mathrm{U}_{\mathrm{eq}}(\mathrm{O})$.

The crystallographic data for the structures reported in this paper have been deposited with the Cambridge Crystallographic Data Centre as supplementary publications no. CCDC 1582965 - 1582968. Copies of available material can be obtained, free of charge, on application to the Director, CCDC, 12 Union Road, Cambridge CB2 1EZ, UK, fax: +44 (0)1223 336033 or Email: deposit@ ccdc.cam.ac.uk. Relevant crystal data are listed in table 1 together with refinement detail.

Table 1. Crystal data, data collection and structure refinement for the four title compounds

\begin{tabular}{|c|c|c|c|c|}
\hline Crystal data & (L1) & (L2) & {$[\mathrm{Ag}(\mathrm{L1})]\left(\mathrm{NO}_{3}\right)$} & {$[\mathrm{Ag}(\mathrm{L} 2)]\left(\mathrm{NO}_{3}\right)\left(\mathrm{H}_{2} \mathrm{O}\right)$} \\
\hline Chemical formula & $\mathrm{C}_{9} \mathrm{H}_{8} \mathrm{~N}_{4} \mathrm{O}$ & $\mathrm{C}_{9} \mathrm{H}_{8} \mathrm{~N}_{4} \mathrm{O}_{2}$ & $\mathrm{C}_{18} \mathrm{H}_{16} \mathrm{AgN}_{8} \mathrm{O}_{2} \cdot \mathrm{NO}_{3}$ & $\begin{array}{c}\mathrm{C}_{9} \mathrm{H}_{8} \mathrm{AgN}_{4} \mathrm{O}_{2} . \mathrm{NO}_{3} . \\
\mathrm{H}_{2} \mathrm{O}\end{array}$ \\
\hline$M_{r}$ & 188.19 & 204.19 & 546.27 & 392.09 \\
\hline $\begin{array}{c}\text { Cell setting, space } \\
\text { group }\end{array}$ & $\begin{array}{l}\text { Orthorhombic, } \\
\qquad \operatorname{Pna} 2_{1}\end{array}$ & $\begin{array}{l}\text { Monoclinic, } \\
\qquad P 2_{1} / n\end{array}$ & $\begin{array}{c}\text { Triclinic, } \\
P \overline{1}\end{array}$ & $\begin{array}{l}\text { Monoclinic, } \\
\qquad P 2_{1} / n\end{array}$ \\
\hline Temperature $(\mathrm{K})$ & $100(2)$ & $100(2)$ & $100(2)$ & $100(2)$ \\
\hline Uni & $\begin{array}{c}\mathrm{a}=22.7284(5) \AA \\
\mathrm{b}=9.8594(2) \AA \\
\mathrm{c}=3.7808(1) \AA \\
\alpha=90^{\circ} \\
\beta=90^{\circ} \\
\gamma=90^{\circ}\end{array}$ & $\begin{array}{c}\mathrm{a}=5.8440(5) \AA \\
\mathrm{b}=21.118(2) \AA \\
\mathrm{c}=7.5764(8) \AA \\
\alpha=90^{\circ} \\
\beta=107.094(5)^{\circ} \\
\gamma=90^{\circ}\end{array}$ & $\begin{array}{l}\mathrm{a}=8.751(5) \AA \\
\mathrm{b}=9.625(5) \AA \\
\mathrm{c}=12.313(5) \AA \\
\alpha=90.081(5)^{\circ} \\
\beta=97.473(5)^{\circ} \\
\gamma=99.838(5)^{\circ}\end{array}$ & $\begin{array}{c}\mathrm{a}=12.5270(4) \AA \\
\mathrm{b}=8.2643(3) \AA \\
\mathrm{c}=12.5996(3) \AA \\
\alpha=90^{\circ} \\
\beta=103.151(3)^{\circ} \\
\gamma=90^{\circ}\end{array}$ \\
\hline$V\left(\AA^{3}\right)$ & $847.23(3)$ & $893.74(15)$ & 1012.9(9) & $1270.16(7)$ \\
\hline$Z$ & 4 & 4 & 2 & 4 \\
\hline$D_{x}\left(\mathrm{Mg} \mathrm{m}^{-3}\right)$ & 1.475 & 1.518 & 1.791 & 2.050 \\
\hline Radiation type & $\mathrm{Cu} K \alpha$ & Mo $K \alpha$ & Mo $K \alpha$ & Mo $K \alpha$ \\
\hline$\mu\left(\mathrm{mm}^{-1}\right)$ & 0.86 & 0.11 & 1.05 & 1.63 \\
\hline Crystal form, colour & Prism, colourless & Prism, colourless & Prism, colourless & Prism, colourless \\
\hline Crystal size (mm) & $0.15 \times 0.10 \times 0.09$ & $0.20 \times 0.10 \times 0.10$ & $0.10 \times 0.10 \times 0.08$ & $0.20 \times 0.10 \times 0.10$ \\
\hline
\end{tabular}




\begin{tabular}{|c|c|c|c|c|}
\hline Diffractometer & $\begin{array}{l}\text { Agilent SuperNova } \\
\text { CCD diffractometer }\end{array}$ & $\begin{array}{l}\text { Agilent SuperNova } \\
\text { CCD diffractometer }\end{array}$ & $\begin{array}{l}\text { Agilent SuperNova } \\
\text { CCD diffractometer }\end{array}$ & $\begin{array}{l}\text { Agilent SuperNova } \\
\text { CCD diffractometer }\end{array}$ \\
\hline $\begin{array}{l}\text { Data collection } \\
\text { method }\end{array}$ & $\omega$-scans & $\omega$-scans & $\omega$-scans & $\omega$-scans \\
\hline $\begin{array}{l}\text { Absorption } \\
\text { correction }\end{array}$ & Integration & Integration & Integration & Integration \\
\hline$T_{\min }, T_{\max }$ & $0.908,0.938$ & $0.889,0.940$ & $0.708,0.750$ & $0.896,0.946$ \\
\hline $\begin{array}{l}\text { No. of measured, } \\
\text { independent and } \\
\text { observed reflections } \\
\qquad(I>2 \sigma(I))\end{array}$ & $15602,1787,1574$ & $8605,2267,1440$ & $21173,6041,4082$ & $32791,6508,4856$ \\
\hline$R_{\text {int }}^{\mathrm{a}}$ & 0.059 & 0.049 & 0.037 & 0.036 \\
\hline$\theta_{\max }\left({ }^{\circ}\right)$ & 76.5 & 28.6 & 30.5 & 37.7 \\
\hline Refinement on & $F^{2}$ & $F^{2}$ & $F^{2}$ & $F^{2}$ \\
\hline $\begin{array}{c}R\left[F^{2}>2 \sigma\left(F^{2}\right)\right]^{\mathbf{b}} \\
\quad w R\left(F^{2}\right)^{\mathbf{c}}, S^{\mathbf{d}}\end{array}$ & $0.053,0.135,1.04$ & $0.057,0.200,1.08$ & $0.041,0.164,1.09$ & $0.029,0.070,1.05$ \\
\hline No. of relections & 1663 reflections & 2267 reflections & 6041 reflections & 2815 reflections \\
\hline No. of parameters & 127 & 136 & 298 & 167 \\
\hline$(\Delta / \sigma)_{\max }$ & $<0.01$ & $<0.01$ & 0.001 & 0.001 \\
\hline$\Delta \rho_{\max }, \Delta \rho_{\min }\left(\mathrm{e} \AA^{-3}\right)$ & $0.60,-0.32$ & $0.42,-0.37$ & $0.63,-0.93$ & $0.75,-0.83$ \\
\hline
\end{tabular}

\subsection{Hirshfeld surface analysis}

In order to have a better understanding of the intermolecular interactions within the crystal structure, Hirshfeld surface analysis [41] has been undertaken. It consists in partitioning the crystal electron density into molecular fragments. Thus, the Hirshfeld surface can be defined as the border between regions where promolecule electron density surpasses that from all neighbouring molecules over the rest of the crystal. The Hirshfeld surface, which envelops the molecule, is defined as an iso-surface of $\mathrm{w}(\mathrm{r})=0.5$, where $\mathrm{w}(\mathrm{r})$ is a molecular weight function derived from the spherically averaged atomic electron densities $\rho_{i}(\mathrm{r})$ [42]: 


$$
w(r)=\frac{\sum \mathrm{i} \in \text { molecule } \rho_{i}(\mathrm{r})}{\sum \mathrm{i} \in \operatorname{crystal} \rho_{i}(\mathrm{r})}
$$

The normalized contact distance $d_{\text {norm }}$ is the sum of the distances of any surface point to the nearest interior $\left(d_{i}\right)$ and exterior $\left(d_{e}\right)$ atom, normalized by the van der Waals radii of the atoms, Spackman et al. [43]. The Hirshfeld surfaces were computed to explore the contributions of non-covalent interactions in the crystal structures using Crystal Explorer 3.1 software [44].

\section{Results and discussion}

\section{FT-IR spectroscopy:}

The spectrum of the triazole Schiff bases, (L1) and (L2), exhibit remarkable bands at 1611 and $1605 \mathrm{~cm}^{-1}$ respectively due to the formation of the imine group $(\mathrm{C}=\mathrm{N})$ [45-46], supp.3 (supplementary materials). Furthermore, the $\mathrm{v}(\mathrm{O}-\mathrm{H})$ bands of the weak intensity were observed in the range $3100-3150 \mathrm{~cm}^{-1}$. These bands do not shift to lower wave number in the spectra of the complexes indicating the non-participation of the imine nitrogen and the hydroxyl group in coordination to the metal ion [47]. In addition, the bands detected in the range of $1300-1500 \mathrm{~cm}^{-1}$ is due to the $\mathrm{V}(\mathrm{N}-\mathrm{N})$ stretching vibration of the triazole moiety. This band is shifted to higher wave number in the complex spectra suggesting the participation of the two nitrogen atoms $\mathrm{N} 1$ and $\mathrm{N} 2$ of triazole in coordination to the metal ion [48].

\section{UV-visible spectroscopy:}

The UV-visible absorption of the four compounds display two bands observed in DMSO in the range of $260-400 \mathrm{~nm}$. The first band observed around $320 \mathrm{~nm}$ is owing to the low energy $\pi-\pi^{*}$ transition of the imine group. The second band detected around $280 \mathrm{~nm}$ was assigned as a moderate $\pi-\pi^{*}$ transition of the aromatic ring table S1 and supp.4 (supplementary materials). These bands undergo a hypsochromic shift due to the coordination of the free ligand with the metal ion.

\section{X-ray structure analysis.}

\section{Crystal structure of (L1) and (L2)}

The crystal structure of ligand (L2) has been reported by François Safin and co-workers [49], however, the data collection was done at room temperature on a twinned crystal, with 
insufficient data to have a good refinement of the structure (Ratio $N O / N V: 6.8$ ). These constraints affected the accuracy of the values of distances and angles.

The molecular structures of the two free ligands (L1) and (L2) are depicted in Fig.1. The two compounds crystallize in the orthorhombic group space Pna2 $2_{1}$ for (L1) and in the monoclinic group space $P 2_{1} / n$ for (L2) with four molecules in the unit cell for each compound. The two Schiff bases (L1) and (L2) differ only by the positions and the nature of the substitutions on the six-membered aromatic ring: (L1) bears a single hydroxyl group at the $\mathrm{C}(6 \mathrm{~A})$ meta position while (L2) presents two hydroxyl substituent at the ortho and para positions. Both (L1) and (L2) are in their enolimine form, confirmed by the lengths of C-O bonds (1.368(3), 1.366(3) and 1.348(8) $⿱$ ), and of C-C single bonds (1.469(3) and 1.451(3) $\AA$ ) and C=N imine bond $(1.278(3)$ and $1.279(3) \AA$ ) (Fig.1). The two molecules have an almost planar $E$ configuration with respect to the imine $\mathrm{C}=\mathrm{N}$ double bond, as indicated by the value of $177.1(2)^{\circ}$ for $(\mathbf{L 1})$ and $177.21(17)^{\circ}$ for $(\mathbf{L 2})$ of the $\mathrm{N}(3 \mathrm{~A})-\mathrm{N}(4 \mathrm{~A})-\mathrm{C}(3 \mathrm{~A})-\mathrm{C}(4 \mathrm{~A})$ torsion angle. The dihedral angles between aromatic rings in both ligands are comparable: $17.16^{\circ}$ for (L1) and $19.51^{\circ}(\mathbf{L 2})$. The bond angles and distances in (L1) and (L2) are in agreement with similar compounds [50-52].

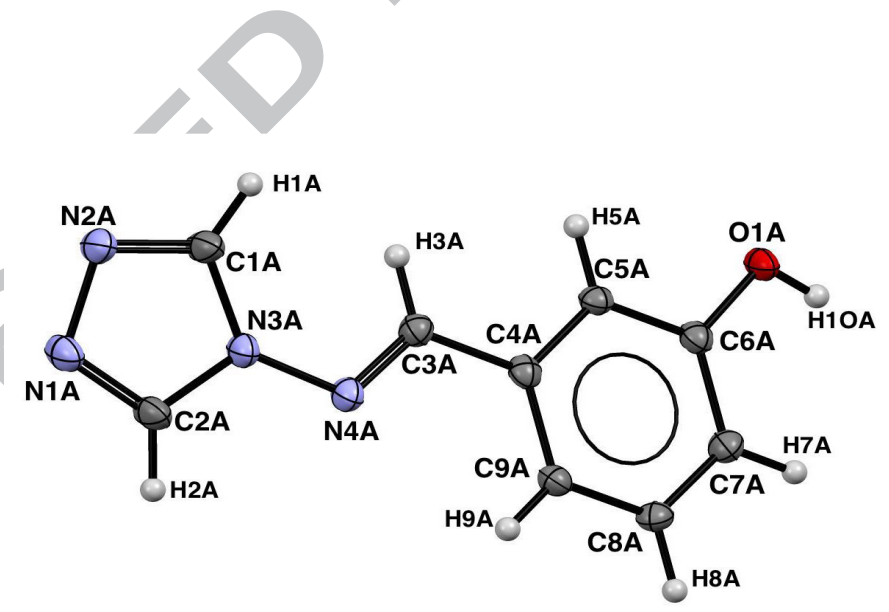

(a) 


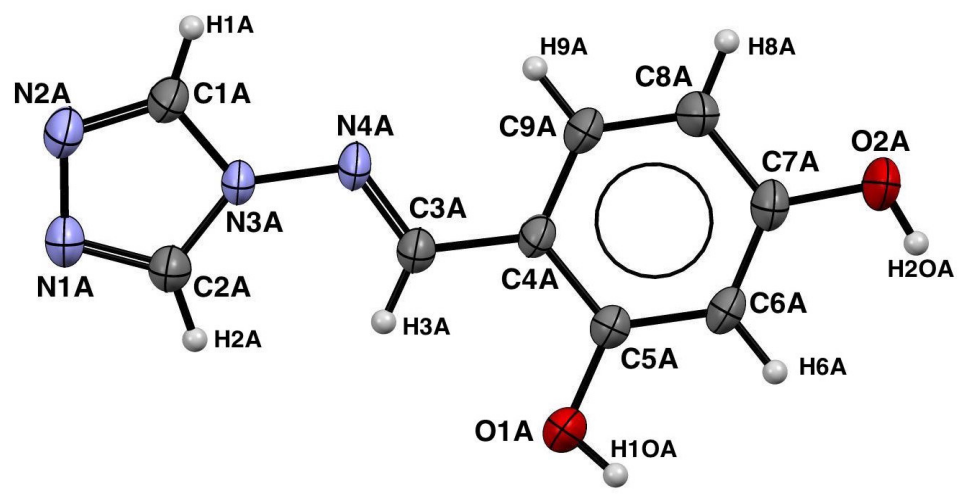

(b)

Fig.1: ORTEP of the two ligands (L1) and (L2) with thermal displacement ellipsoids drawn at the $50 \%$ probability level. (a) (L1) and (b) (L2).

In the crystal structures formed by (L1) and (L2), the nitrogen atoms of triazole moieties interact with hydroxyl group through intermolecular O-H...N hydrogen bonds. In the case of (L1), the single hydroxyl group is hydrogen bonded to $\mathrm{N}(1 \mathrm{~A})$ allowing to form infinite chains along $\boldsymbol{a}$ axis with a C(10) graph set motif [53-54]. The presence of the second $\mathrm{OH}$ in the case of (L2) has drastic consequences for the crystal packing. It leads indeed to the formation of another $\mathrm{O}-\mathrm{H} \ldots \mathrm{N}$ hydrogen bond involving the second triazole nitrogen atom, transforming the infinite chain observed in the case of (L1) into $\mathrm{R}_{4}{ }^{4}(29)$ rings, generating two-dimensional layers developing parallel to the (101) plane (Fig.2) and (table S2 in supplementary materials). These hydrogen bonds replace the intramolecular ones between $o-\mathrm{OH}$ and imine nitrogen atom which are broken by the rotation of the phenolic ring [55].

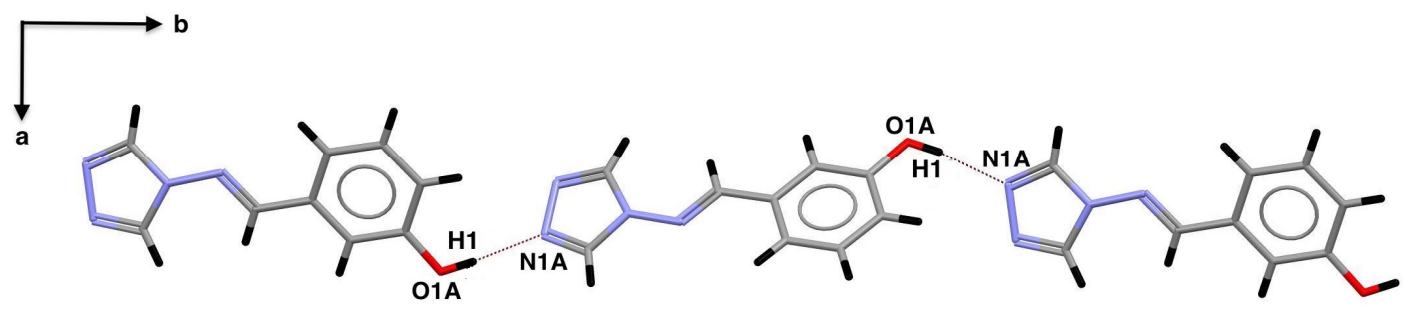

(a) 


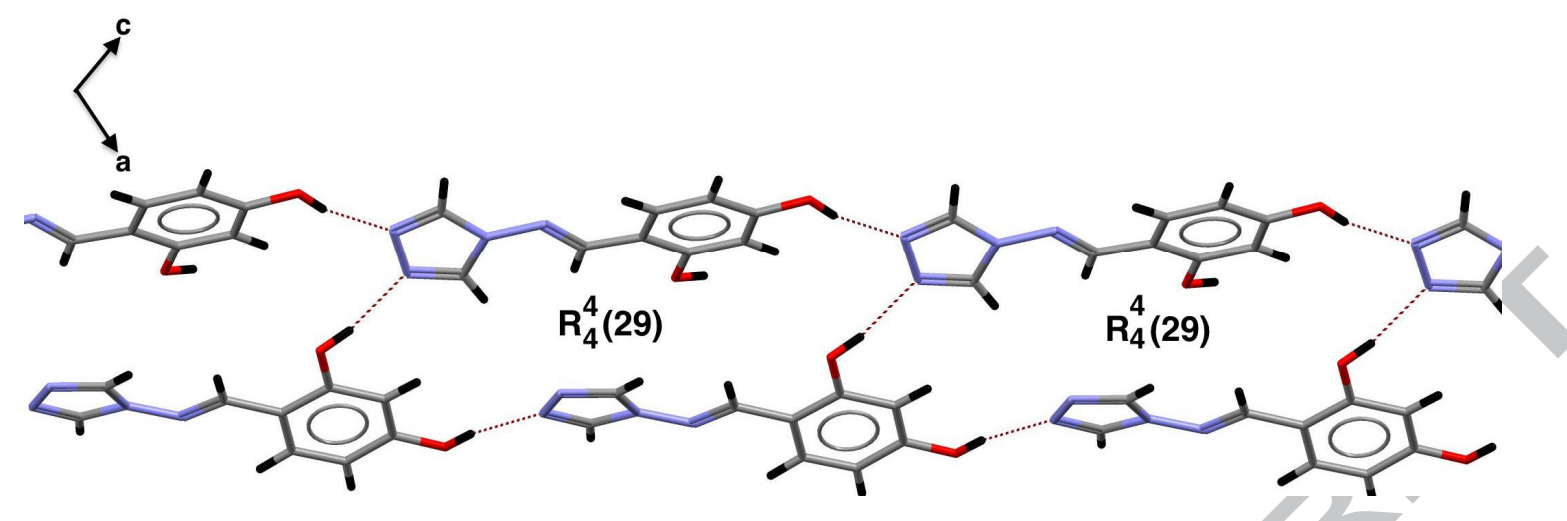

(b)

Fig.2: O-H...N hydrogen bonds. (a) Infinite chains in (L1) and 2D layers (b) in (L2)

In (L1), the azomethine nitrogen (N4A), which is not involved in O-H...N interaction, acts nevertheless as acceptor in a C4A-H4A...N4A hydrogen bond along $\boldsymbol{b}$ axis, giving rise to $2 \mathrm{D}$ layers built on the basis of alternating $\mathrm{R}_{6}{ }^{6}(33)$ and $\mathrm{R}_{3}{ }^{3}(18)$ rings, (Fig.3a). Moreover, along the third direction ( $\boldsymbol{c}$ axis), C1A-H1 ...O1A bonds between triazole and hydroxyl, and C2A$\mathrm{H} 2 \mathrm{~A}$....N1A bond between two triazole moieties ensure the supramolecular cohesion of the 2D layers, (Fig.3b). The same C-H...O hydrogen bond links the 2D layers in (L2) along the $\boldsymbol{b}$ axis and leads to a three dimensional structure. In both crystal structures, $\pi \ldots \pi$ interactions coexist with hydrogen bonding and participate in the final stability of the molecular assemblies. As shown in Fig.4, in the case of (L1), the crystal packing presents clear triazole ... triazole and phenyl...phenyl $\pi \ldots \pi$ interactions. In the case of (L2), a single weaker $\pi \ldots \pi$ stacking appears to form partially between the phenyl ring of a molecule and both the triazole moiety and the imine double bond of the symmetry equivalent molecule obtained by translation along the $\boldsymbol{a}$ axis. 


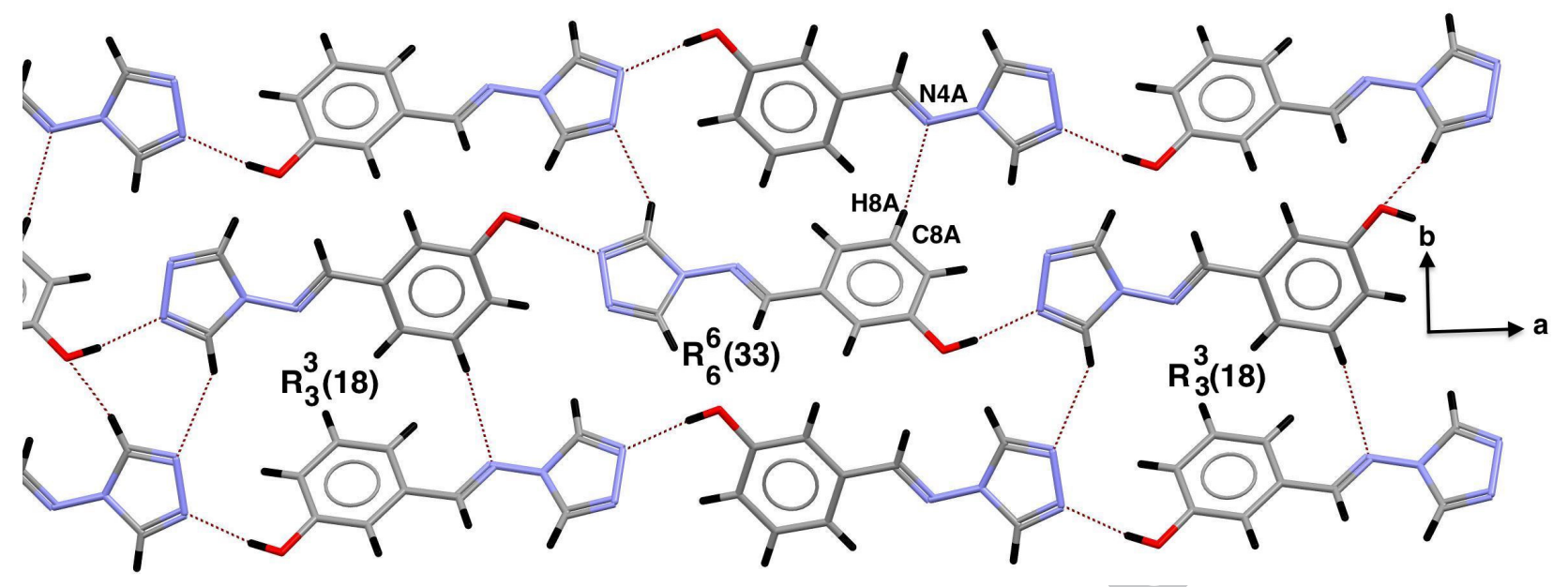

(a)

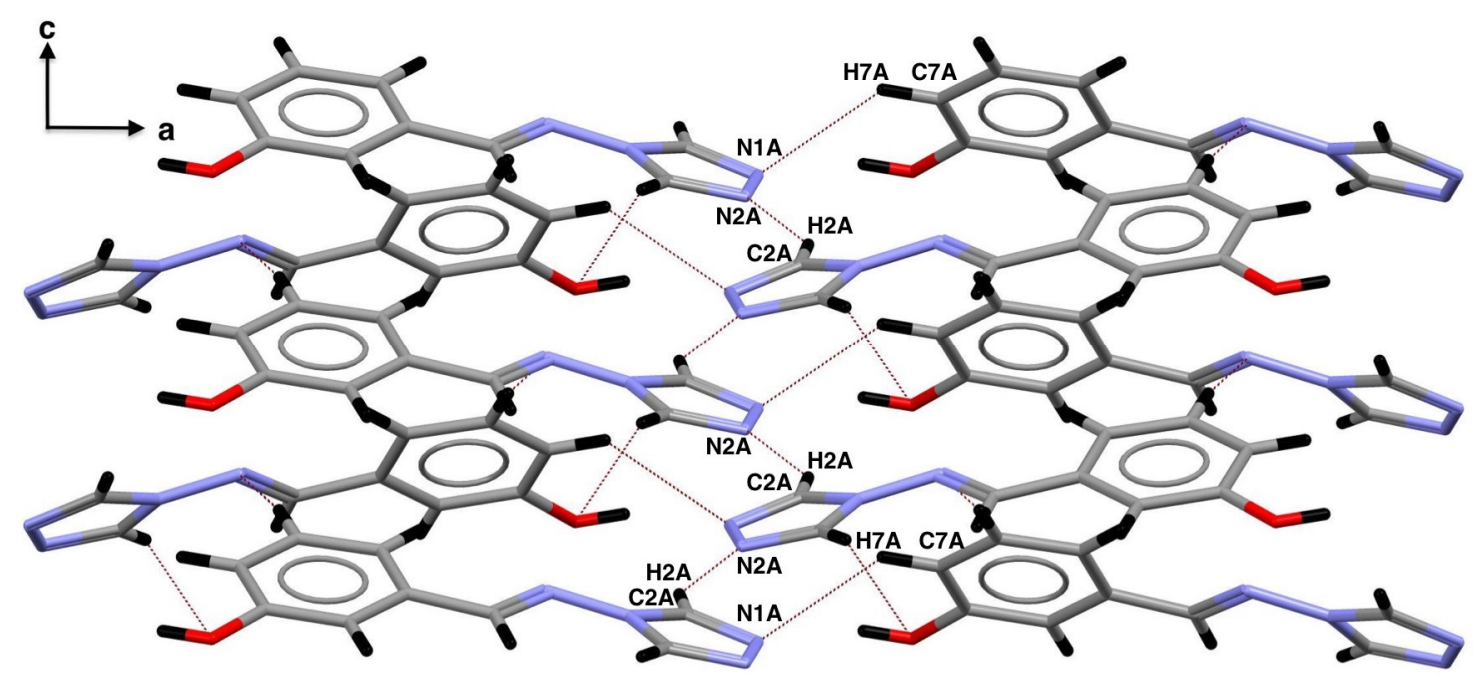

(b)

Fig 3: C-H... N and C-H...O hydrogen bonds in (L1). (a) 2D layers generated by interactions involving azomethine nitrogen atoms. (b) Supramolecular structure of (L1). 


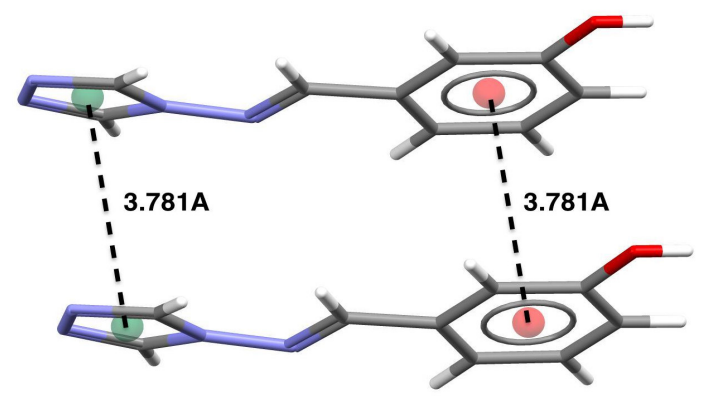

(a)

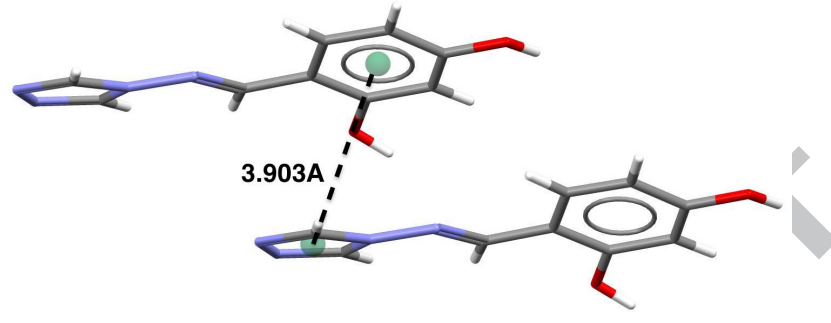

(b)

Fig.4: $\pi \ldots \pi$ interactions.

(a) phenyl...phenyl and triazole...triazole in (L1). (b) phenyl...triazole in (L2)

\section{Crystal structure of the silver complexes $[\mathrm{Ag}(\mathrm{L1})]\left(\mathrm{NO}_{3}\right)$ and $[\mathrm{Ag}(\mathrm{L2})]_{\mathbf{n}}\left(\mathrm{NO}_{3}\right)_{\mathbf{n}}\left(\mathrm{H}_{2} \mathrm{O}\right)$}

Reaction of $\mathrm{AgNO}_{3}$ with (L1) and (L2) yield a $\mathrm{Ag}(\mathrm{I})$ dimer for the first ligand and a polymer for the second one. As observed in the crystal structures of the isolated ligands, the presence of an extra hydroxyl group in (L2) compared to (L1) led to very different crystal structures of their corresponding silver complexes. The structure of the dimer issued by (L1) contains a dinuclear cation formed by two-symmetry related $\operatorname{Ag}(\mathrm{I})$ coordinated to four (L1) ligands, [Ag $\left.\mathbf{A g}_{2}(\mathbf{L 1})_{4}\right]$, and uncoordinated $\mathrm{NO}_{3}^{-}$anions, Fig.5. Each $\mathrm{Ag}(\mathrm{I})$ ion adopts a trigonal environment and the sum of angles around it, equal to $360.0^{\circ}$, indicates planarity of its geometry [56-57]. $\operatorname{Ag}(\mathrm{I})$ and $\operatorname{Ag}(\mathrm{I})(\mathrm{i})$ [(i) 2-x, 1-y, 1-z] are bridged by two ligands, hereafter noted $\mathrm{A}$ and $\mathrm{B}$, to form a six-membered ring $\left\{\mathrm{Ag}_{2} \mathrm{~N}_{4}\right\}$. The $\operatorname{Ag}(\mathrm{I}) \ldots \operatorname{Ag}(\mathrm{I})$ separation is 3.917 $\AA$, which is significantly longer than the sum of the van der Waals radii of two $\operatorname{Ag}(\mathrm{I})$ cations

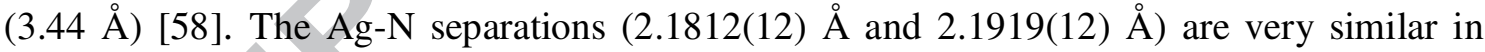
structures with such coordination bonds [59]. The ligand A is bitopic with the two nitrogen atoms $\mathrm{N}(1 \mathrm{~A})$ and $\mathrm{N}(2 \mathrm{~A})$, however, ligand $\mathrm{B}$ interacts with $\mathrm{Ag}(\mathrm{I})$ by only one nitrogen atom (N1B). The dihedral angles formed between the aromatic and triazole rings are $4.63^{\circ}$ for $\mathrm{A}$ and $7.65^{\circ}$ for $\mathrm{B}$, much less than the $17.16^{\circ}$ observed for the free ligand (L1), which indicate that they are nearly coplanar in the silver complex. In $[\mathbf{A g}(\mathbf{L 1})]\left(\mathbf{N O}_{3}\right)$, the O-H...N interaction, between two ligands, organizes the dimers into polymeric chains, built on the succession of $\mathrm{R}_{2}{ }^{2}(32)$ rings and developing in the [110] direction, Fig.6. O-H... and C$\mathrm{H}$...O hydrogen bonds between ligands and nitrate anion organize these chains into 3D supramolecular network. In addition, $\pi \ldots \pi$ and $\mathrm{Ag} . . . \pi$ interactions in conjunction with all hydrogen bonds contribute to the stability of the structure. 
In the crystal structure of the second complex, $[\mathbf{A g}(\mathbf{L 2})]_{\mathbf{n}}\left(\mathbf{N O}_{3}\right)_{\mathbf{n}}\left(\mathbf{H}_{2} \mathbf{O}\right)$, the coordination geometry of $\mathrm{Ag}(\mathrm{I})$ ion is square pyramidal with a basal plane constituted by $\mathrm{N}(1 \mathrm{~A})$ and $\mathrm{N}(2 \mathrm{~A})$ triazole nitrogen atoms in two (L2) molecules and by oxygen atoms of two $\mathrm{NO}_{3}{ }^{-}$anions. The apical direction of the square pyramid is defined by the $\mathrm{O}(1 \mathrm{~A})$ atom of the phenyl hydroxyl group located at ortho position. $\mathrm{Ag}(\mathrm{I})$ ions, being coordinated by the nitrogen atoms of triazole moiety, is found in distorted linear geometry $\left(\mathrm{N}(1 \mathrm{~A})-\mathrm{Ag}(1)-\mathrm{N}(2 \mathrm{~A})\right.$ of $\left.179.31(5)^{\circ}\right)$. This slight deviation from perfect linear geometry, is essentially due to the weak $\mathrm{Ag}$... O interactions between $\operatorname{Ag}(\mathrm{I})$ and nitrate anion on one side and hydroxyl group on the other side

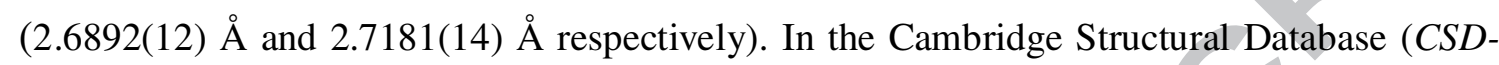
2017, update Feb 2017), only two structures are reported considering these two weak interactions as $\mathrm{Ag}-\mathrm{O}$ bond [60]. $\mathrm{Ag}(\mathrm{I})$ ions are connected via bridging ligand molecules to form polymeric chains along $\boldsymbol{b}$ axis Fig.7. The dihedral angle between triazole and phenyl rings in the bitopic ligand (L2) in this polymer is the same as found for the free one $\left(19.52^{\circ}\right)$.

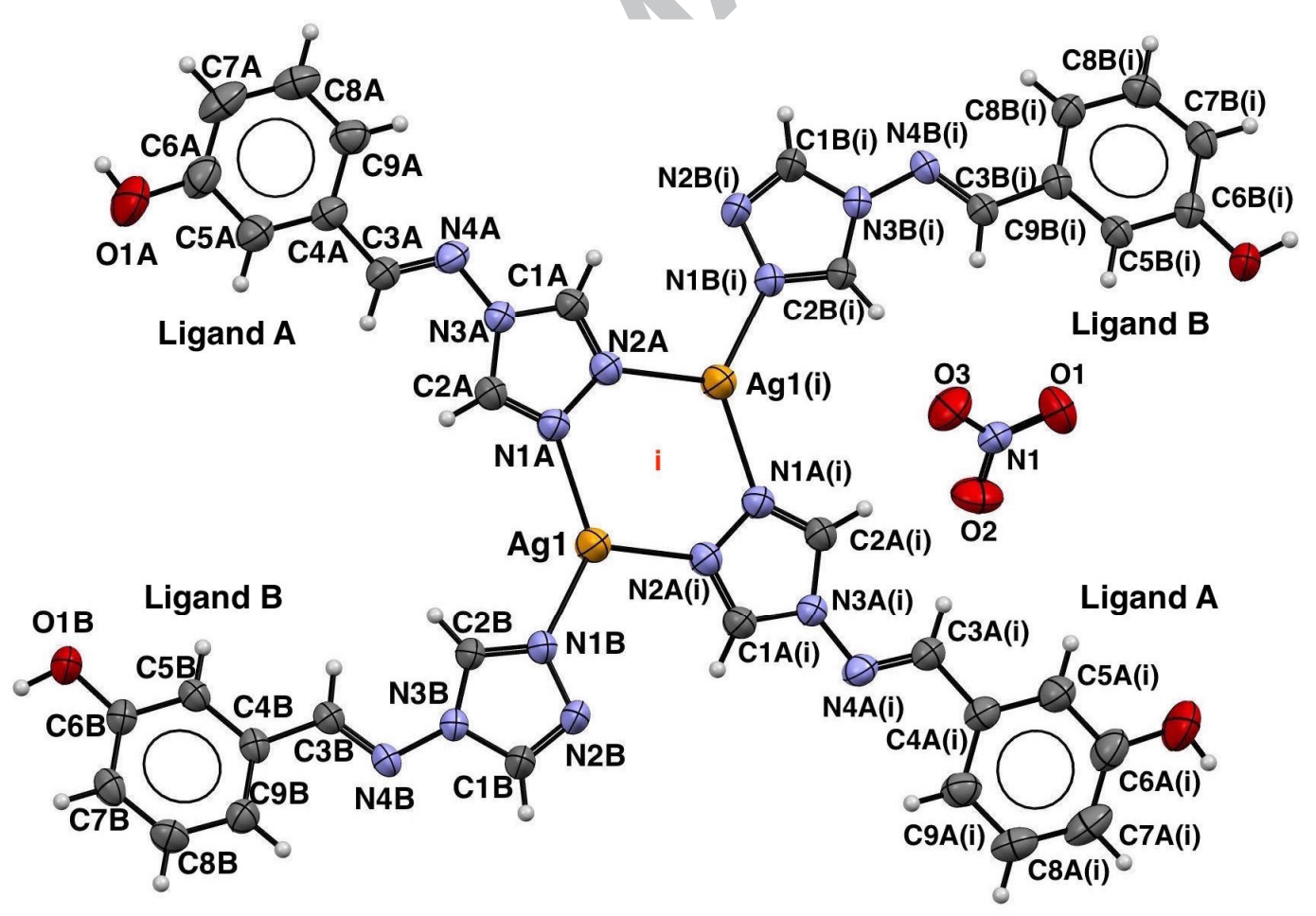

Fig.5: ORTEP representation of the dimer of $[\mathbf{A g}(\mathbf{L 1})]\left(\mathbf{N O}_{3}\right)$ with thermal displacement ellipsoids drawn at the $50 \%$ probability level. (i) $2-x, 1-y, 1-z$ 


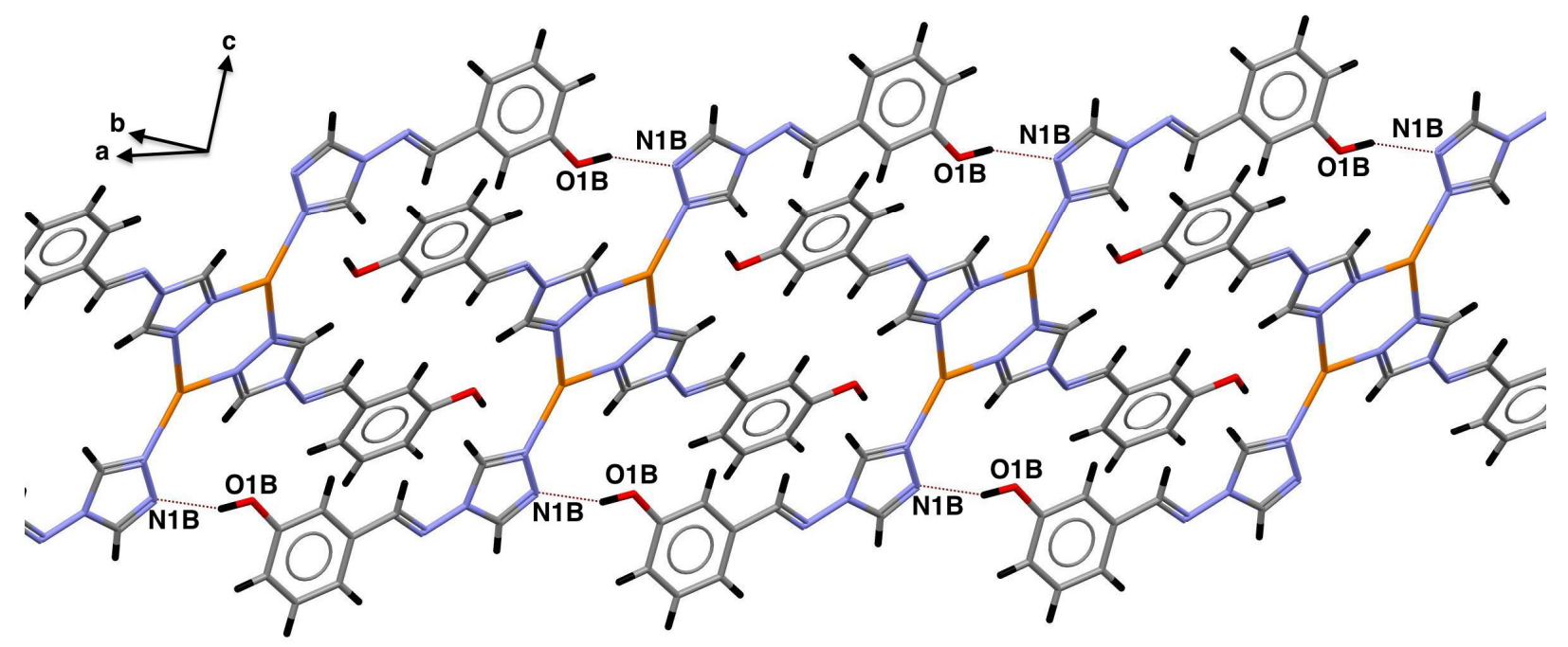

Fig.6: Interligand O-H... N hydrogen bond connecting dimers

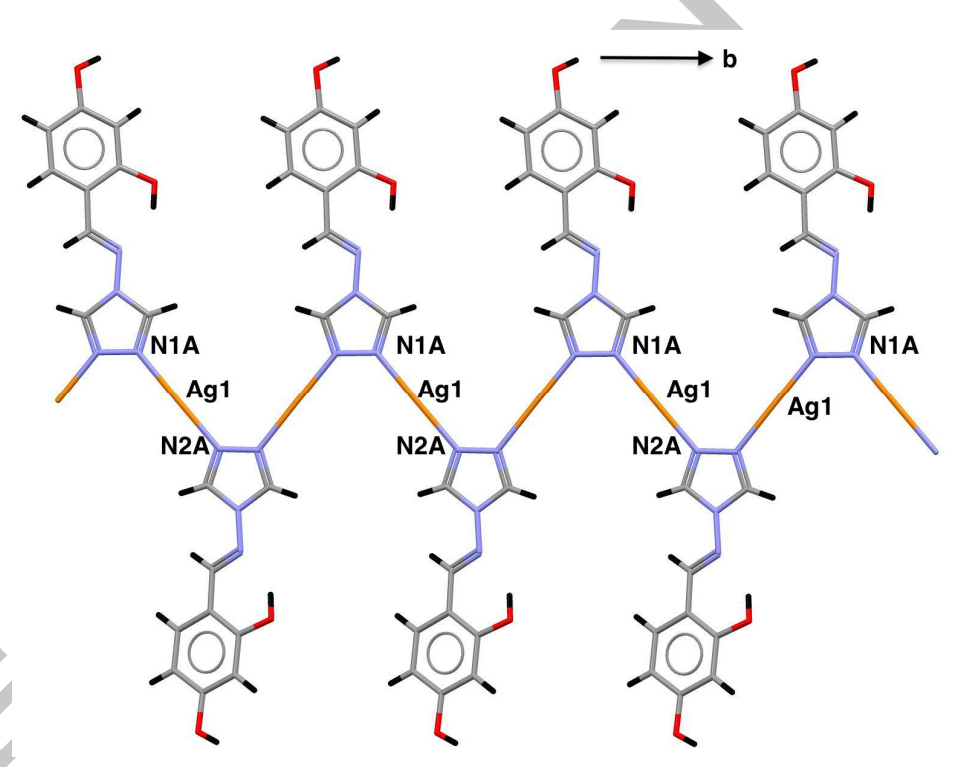

Fig.7: Polymeric chains of $[\mathrm{Ag}(\mathbf{L 2})]_{\mathbf{n}}\left(\mathrm{NO}_{3}\right)_{\mathbf{n}}\left(\mathbf{H}_{2} \mathrm{O}\right)$ developing along $b$ axis

Interestingly, unlike in the free (L2) ligand, in the polymer $[\mathbf{A g}(\mathbf{L 2})]_{\mathbf{n}}\left(\mathbf{N O}_{\mathbf{3}}\right)_{\mathbf{n}}\left(\mathbf{H}_{\mathbf{2}} \mathbf{O}\right)$, one $\mathrm{S}(6)$ intra-ligand $\mathrm{O}-\mathrm{H} \ldots \mathrm{N}$ hydrogen bond is observed between the $o-\mathrm{OH}$ group of the phenyl ring and the azomethine nitrogen atom, Fig.8. O-H...O hydroxyl-water hydrogen bonds connect polymeric chains in 2D sheets parallel to (bc) plane C-H...O ligand-nitrate anion and $\pi \ldots \pi$ interactions reinforce the crystal structure and contribute to the construction of 3D supramolecular network. In the structure of $[\mathrm{Ag}(\mathbf{L 2})]_{\mathbf{n}}\left(\mathbf{N O}_{3}\right)_{\mathbf{n}}\left(\mathrm{H}_{\mathbf{2}} \mathbf{O}\right)$, the presence of a structured water molecule is 
noteworthy. This water molecule fills a void formed by five (L2) molecules and a $\mathrm{NO}_{3}{ }^{-}$ion and is involved in three hydrogen bonds: two as donor to oxygen atoms of $\mathrm{a} \mathrm{NO}_{3}{ }^{-}$ion and of a hydroxyl group of the ligand, and one as acceptor of hydrogen atom of the same hydroxyl group located in a symmetry related molecule (Fig.8). This water molecule has probably a significant impact on the packing stability as the hydrogen bonds in which it is involved are among the shortest in the crystal structure, with oxygen-oxygen distances of 2.617(2) and 2.812(2) $\AA$ (see Table S3 in supplementary materials).

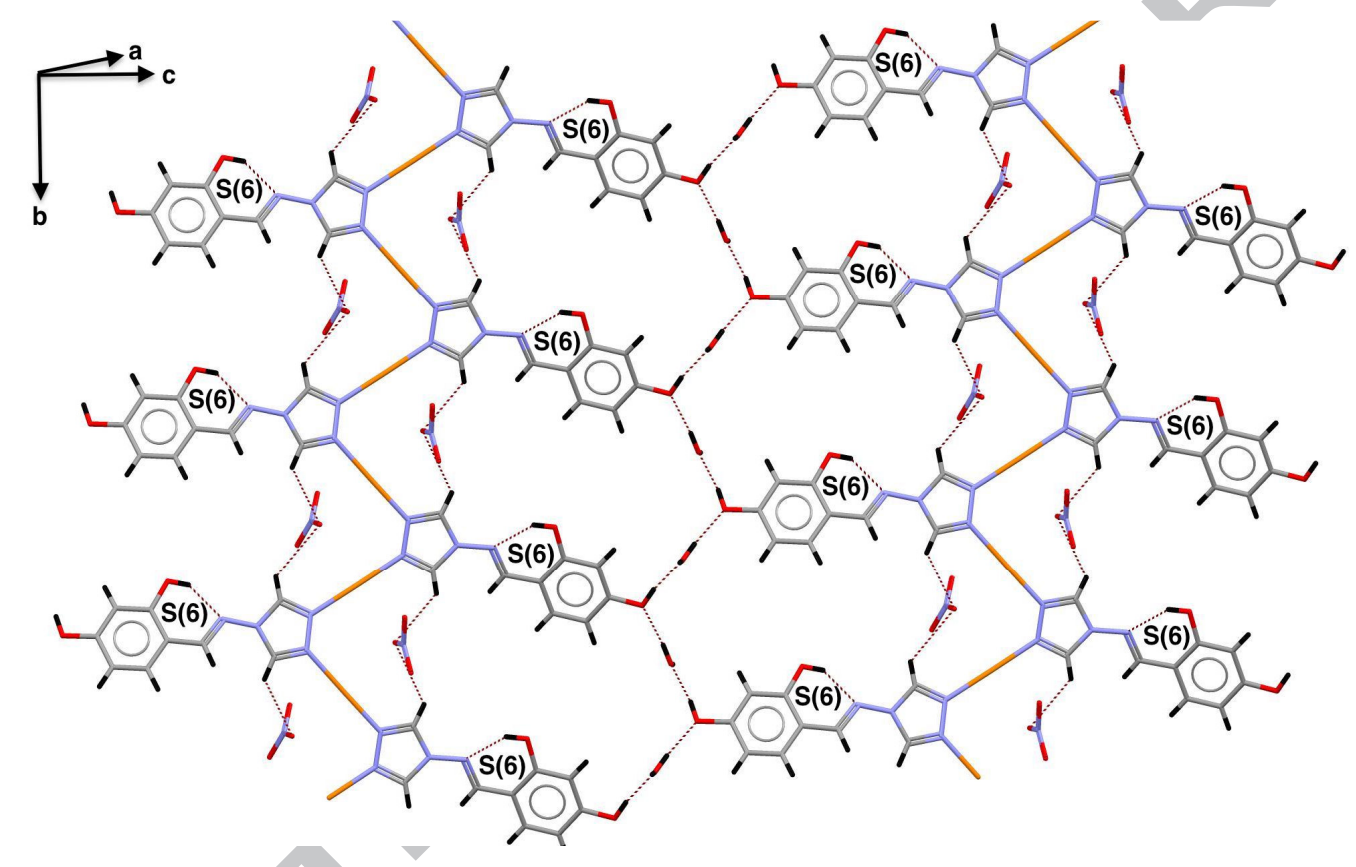

Fig.8: 2D Sheets built on the basis of $\mathrm{O}-\mathrm{H} \ldots \mathrm{O}$ and $\mathrm{O}-\mathrm{H} \ldots \mathrm{N}$ hydrogen bonds in $[\mathrm{Ag}(\mathrm{L2})]_{\mathbf{n}}\left(\mathrm{NO}_{3}\right)_{\mathbf{n}}\left(\mathrm{H}_{2} \mathrm{O}\right)$

\section{Hirshfeld surfaces analyses of (L1), (L2):}

The intermolecular interactions within the crystal structures of the ligands (L1) and (L2), and of their silver complexes were analysed by combining 3D Hirshfeld surface and 2D fingerprint plots. A better understanding of the molecular structure requires quantitative insights into the relative contributions of intermolecular interactions within the crystal [61]. For that purpose, Hirshfeld surfaces of the title compounds have been generated, and mapped over dnorm value (Fig. 9). The red hot spots on the surface indicate the presence of atoms in very close proximity to the outside of the Hirshfeld surface. The white surface means that the 
atoms are in medium proximity, while the blue surface shows little proximity of outside atoms.

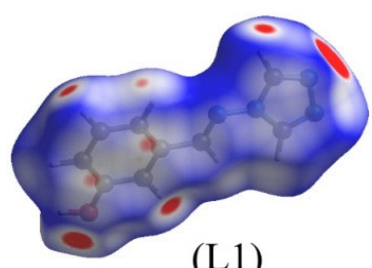

(L1)

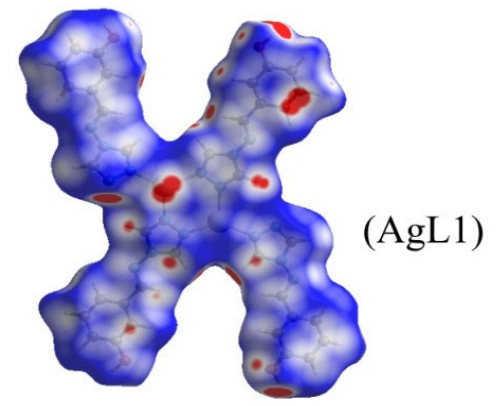

Fig. 9: Hirshfeld surfaces of the title compounds mapped with

$$
d_{\text {norm }}=\frac{d_{i}-r_{i}^{v d W}}{r_{i}^{v d W}}+\frac{d_{e}-r_{e}^{v d W}}{r_{e}^{v d W}}
$$

Recently, these type of triazole compounds have been studied by Safin et al. [49]. In this paper we have used the Hirshfeld surfaces and 2D fingerprint plots analyses to perform a comparative study of the intermolecular interactions in two different families, the free ligands and their silver complexes. From the combination of the 3D Hirshfeld surface and 2D fingerprint plots of the (L1) and (L2) compounds, we notice that the intermolecular H...H contacts have the main contribution, corresponding to $31.3 \%$ and $29.5 \%$ of the total Hirshfeld surfaces areas (supp.5). For (L1) we observe the presence of short intermolecular H...H contact where $d_{e}=d_{i} \approx 1.13 \AA$. Two red spots are depicted on the $d_{\text {norm }}$ surfaces, Fig.10. On the other hand, the intermolecular H...H contacts for (L2) are bit longer in the vicinity of 2.65 and $2.86 \AA$, these contacts are manifested as white spots on $d_{\text {norm }}$ which are considered as weak interaction.

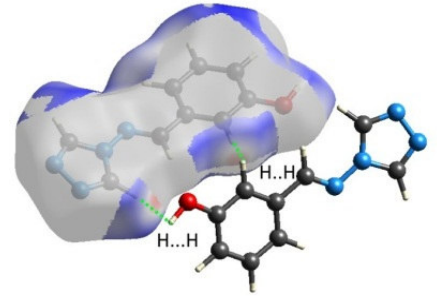

(L1)

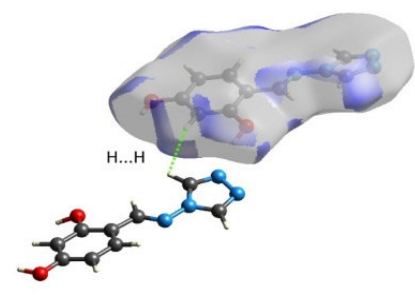

(L2) 
Fig. 10: Hirshfeld surfaces mapped with $d_{\text {norm }}$ for (L1) and (L2) showing H...H contacts

As shown previously, the stabilization of the crystal structure is provided for the two structures by hydrogen bonds. In the fingerprint plots of both (L1) and (L2), N...H contacts are depicted in supp.5 (supplementary materials), as a pair of sharp spikes at $d_{e}+d_{i} \approx 1.8 \AA$. These contacts in the two structures (L1) and (L2) have considerable contribution on Hirshfeld surface of $27.3 \%$ and $23.3 \%$, respectively (Fig. 12).

The red spots on the $d_{\text {norm }}$ surfaces in Fig.11 are due to the $H_{C} \ldots . N$ and $H_{O} \ldots . . N$ contacts corresponding to C-H..N and O-H...N hydrogen bonds, respectively. Thus, in the $d_{\text {norm }}$ suface

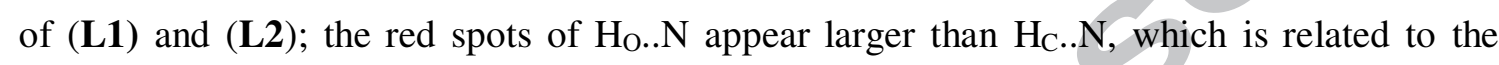
hydrogen bonds interaction distances, and hence to their strength.

(L1)
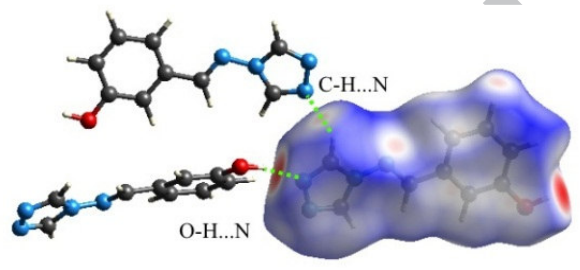

(L2)

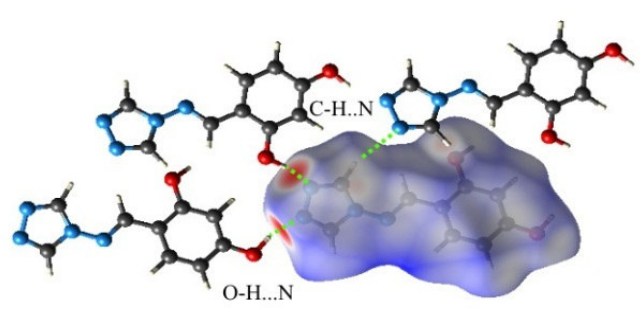

Fig.11: Hirshfeld surfaces mapped with $\mathrm{d}_{\text {norm }}$ for (L1) and (L2) showing O-H...N and C-

\section{H...N hydrogen bonds}

The ligand (L2) contains an extra $\mathrm{OH}$ function in the phenolic part of the molecule compared to $(\mathbf{L 1})$. As expected, this function increases the proportion of O...H contacts, and decreases the C...H ones, on Hirshfeld surface in (L2). The O...H contacts show up as a sharp spike in the fingerprint plots of the molecules at $d_{e}+d_{i} \approx 2.4 \AA$. The packing cohesion of the two structures is also provided by C...H interactions, representing $16.4 \%$ and $11.3 \%$ of the total surface area for (L1) and (L2), respectively, (supp.5 and supp.6). As stated in the previous section, $\pi \ldots \pi$ stacking interactions also contribute to the cohesion of the crystal packing. Such interactions appear on Hirshfeld surfaces as $\mathrm{C} \ldots \mathrm{C}$ and $\mathrm{C} \ldots \mathrm{N}$ intermolecular contacts. However, these contacts in the two structures represent a small proportion of the total 
Hirshfeld surface areas. The fingerprint plots show the C...N interactions as a region of blue/green colour on the diagonal at $d_{e} \approx d_{i} \approx 1.80 \AA$ (supp.5 and supp.6).

In the study by Safin et al. [49] the same molecule (L2) had different fingerprint plots (Fig .12), reflecting differences in the structures due to the way the X-ray data were collected. The fingerprint plot is highly sensitive to the environment surrounding the molecule, and unique for each molecule in a particular polymorphic form [42]. The distinction can be observed in the contribution of each intermolecular contacts and in the sum of $d_{e}, d_{i}$. Furthermore, the area and the volume closed by Hirshfeld surfaces $\left(223.56 \AA^{2}, 218.04 \AA^{3}\right)$ for (L2) and $\left(222.81 \AA^{2}\right.$, $216.60 \AA^{3}$ ) for the same one previously reported by Safin and co-workers, named in this work (L2bis), show this distinction [49]. The packing energy $(P E)$ is one of the most important property which can be calculated to characterize the crystal packing cohesion. Using the dispersive-repulsive forces only, the packing energy can be approximated by the empirical formula developed by Gavezzotti and Filippini studying the geometry of intermolecular X$\mathrm{H} . . \mathrm{Y}(\mathrm{X}, \mathrm{Y}=\mathrm{N}, \mathrm{O})$ hydrogen bond and the calibration of its empirical potentials [62]:

$$
P E=\frac{1}{2} \sum \sum E\left(R_{i j}\right) \text { where } E\left(R_{i j}\right)=A \exp \left(-B R_{i j}\right)-C R_{i j}^{-6}
$$

Using this potential as implement in the software « Mercury CSD 2.0 - New Features for the Visualization and Investigation of Crystal Structures » [63], the packing energies of (L1) and (L2) crystal structures are $-153.4 \mathrm{~kJ} / \mathrm{mol}$ and $-191.4 \mathrm{~kJ} / \mathrm{mol}$, respectivly. The fact that the crystal structure of ligand (L2) appears more stable than the one of (L1) can be explained by the extra $\mathrm{OH}$ function which gives more stability to the crystal packing, and by the presence of the water molecule mediating intermolecular interactions by strong $\mathrm{O}-\mathrm{H}$... O hydrogen bonds [64].

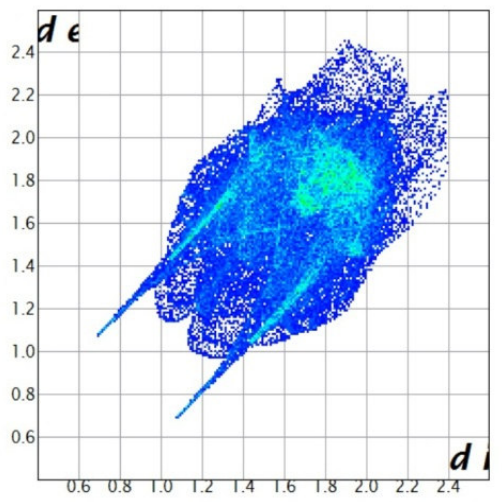

(L2)

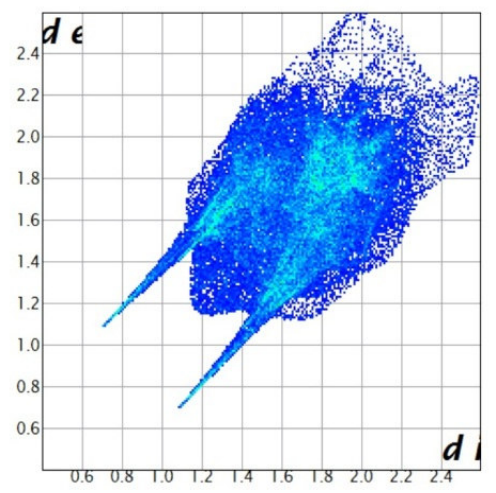

(L2bis)

Fig.12: 2D Fingerprint plot of (L2, this work) and (L2bis, Safin et al. [49]) 
Hirshfeld surfaces analyses of $[\mathrm{Ag}(\mathrm{L1})]\left(\mathrm{NO}_{3}\right)$ and $[\mathrm{Ag}(\mathrm{L2})]_{n}\left(\mathrm{NO}_{3}\right)_{n}\left(\mathrm{H}_{2} \mathrm{O}\right)$ :

The fingerprint plots of the silver complexes are drastically different from the ones obtained from the crystal structures of the free ligands.

The main share of total Hirshfeld surface for the complexes $[\mathbf{A g}(\mathbf{L 1})]\left(\mathbf{N O}_{3}\right)$, $[\mathbf{A g}(\mathbf{L 2})]_{\mathrm{n}}\left(\mathbf{N O}_{3}\right)_{\mathrm{n}}\left(\mathbf{H}_{2} \mathbf{O}\right)$ is attributed to O...H interactions with $21.4 \%$ and $25.8 \%$ of the total surfaces, respectively. O...H interactions appear as two sharp spikes in the fingerprint plots of the two complexes (supp.5). The upper spike in bottom left (donor) region of the fingerprint plot where $\left(d_{e}=1.19, \AA d_{i}=0.83 \AA\right)$ for $[\mathbf{A g}(\mathbf{L 1})]\left(\mathbf{N O} \mathbf{O}_{3}\right)$ and $\left(d_{e}=1 \AA, d_{i}=0.65 \AA\right)$ for $[\mathbf{A g}(\mathbf{L 2})]_{\mathrm{n}}\left(\mathbf{N O}_{3}\right)_{\mathrm{n}}\left(\mathbf{H}_{2} \mathbf{O}\right)$ involves $17.5 \%$ and $19.9 \%$ of the total surface, respectively. The lower spike which correspond to the hydrogen-bond acceptor in the region $\left(d_{e}=1.1 \AA\right.$, $d_{i}=$ $1.4 \AA)$ for $[\mathbf{A g}(\mathbf{L 1})]\left(\mathbf{N O}_{3}\right)$ and $\left(d_{e}=0.7 \AA, d_{i}=1.1 \AA\right)$ for $[\mathbf{A g}(\mathbf{L 2})]_{\mathrm{n}}\left(\mathbf{N O}_{3}\right)_{\mathrm{n}}\left(\mathbf{H}_{2} \mathbf{O}\right)$ corresponds to $4 \%$ and $5.9 \%$ of the total surface, respectively. With a comparable proportion than for O...H interactions, H...H contacts account for the quarter of the total Hirshfeld surfaces area of each complex. These contacts are showed in the middle of scattered points in the fingerprint plots (supp.5). Furthermore, in the $[\mathbf{A g}(\mathbf{L 1})]\left(\mathbf{N O}_{3}\right)$ structure N...H contacts play the main role in the stabilization of crystal packing. The N...H contact are observable as a very sharp spike $\left(d_{e}=0.9 \AA, d_{i}=1.19 \AA\right.$ ) (Supp.5). Interestingly, these contacts represent $16.9 \%$ of the total surface, while only $7.2 \%$ for $[\mathbf{A g}(\mathbf{L} 2)]_{\mathrm{n}}\left(\mathbf{N O}_{3}\right)_{\mathrm{n}}\left(\mathbf{H}_{2} \mathbf{O}\right)$. The $\pi \ldots \pi$ stacking (C...C) contacts is manifested in the 2D fingerprint plot, (Supp.5), as a region of blue/green colour $\left(d_{e}=d_{i} \approx 1.65 \AA\right)$ corresponding to an interlayer distance of $3.3 \AA$ for $[\mathbf{A g}(\mathbf{L 1})]\left(\mathbf{N O}_{3}\right)$. For $[\mathbf{A g}(\mathbf{L 2})]_{\mathrm{n}}\left(\mathbf{N O}_{3}\right)_{\mathrm{n}}\left(\mathbf{H}_{2} \mathbf{O}\right)$ the $\pi \ldots \pi$ stacking are visible in the fingerprint plot where $\left(d_{e}=d_{i}\right.$ $\approx 1.8 \AA$ ) corresponding to an interlayer distance of $3.6 \AA$. The pattern of red and blue triangles on the Hirshfeld surface coloured by the shape index value is characteristic of $\pi \ldots \pi$ stacking (Fig.13). 


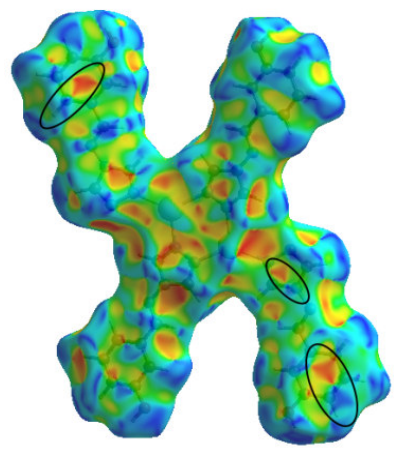

-[Ag(L1) ](NO3)-

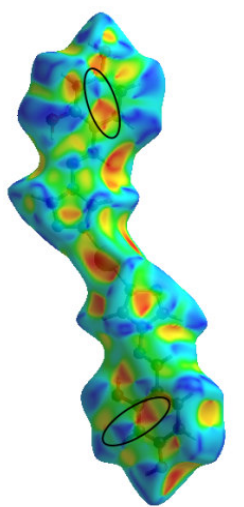

-[Ag(L2)]n(NO3)n(H2O)-

Fig.13 : Hirshfeld surfaces mapped with shape index (front and back views) for

$[\mathrm{Ag}(\mathrm{L1})]\left(\mathrm{NO}_{3}\right)$ and $[\mathrm{Ag}(\mathrm{L2})]_{\mathbf{n}}\left(\mathrm{NO}_{3}\right)_{\mathbf{n}}\left(\mathrm{H}_{2} \mathrm{O}\right)$.

The C...H interactions appear as wings in fingerprint plot for both structures $[\mathrm{Ag}(\mathbf{L 1})]\left(\mathbf{N O}_{3}\right)$ and $[\mathrm{Ag}(\mathbf{L 2})]_{\mathbf{n}}\left(\mathbf{N O}_{3}\right)_{\mathbf{n}}\left(\mathbf{H}_{2} \mathbf{O}\right)$. These contacts occupy $12 \%$ and $9.2 \%$ of the total Hirshfeld surface area, respectively.

The counter-ion $\mathrm{NO}_{3}{ }^{-}$contribute in the cohesion of the crystal packing. Its oxygen atoms are involved in C-H...O and O-H...O hydrogen bonds in both structures, (Fig.14). The Hirshfeld surface around the counter-ion in $[\mathbf{A g}(\mathbf{L 2})]_{\mathbf{n}}\left(\mathbf{N O}_{3}\right)_{\mathbf{n}}\left(\mathbf{H}_{\mathbf{2}} \mathbf{O}\right)$ shows the interactions between oxygen and $\operatorname{Ag}(\mathrm{I})$ cations which represent $15.7 \%$ of the total surface (Fig. 15(c-d)).
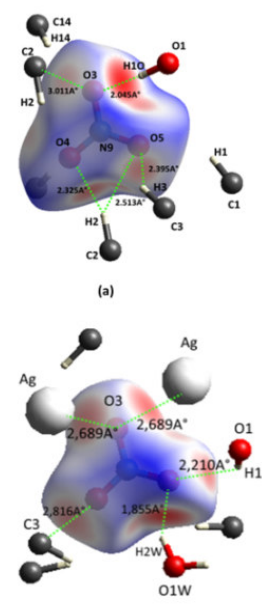
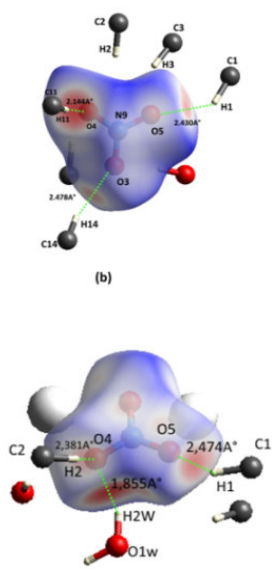

(d)

Fig.14: Hirshfeld surfaces mapped with $d_{\text {norm }}$ for $\mathrm{NO}_{3}{ }^{-}$in the $[\mathbf{A g}(\mathbf{L 1})]\left(\mathbf{N O}_{3}\right)$ $(\mathrm{a}, \mathrm{b})$ and $[\mathbf{A g}(\mathbf{L 2})]_{\mathbf{n}}\left(\mathbf{N O}_{3}\right)_{\mathbf{n}}\left(\mathbf{H}_{\mathbf{2}} \mathbf{O}\right)(\mathrm{c}, \mathrm{d})$ crystal structures. The surfaces are shown in two different orientations

In order to acquire a better understanding of the silver contribution in the crystal lattice cohesion, the atomic Hirshfeld surface analysis has been undertaken. The Hirshfeld surface 
around $\mathrm{Ag}(\mathrm{I})$ mapped over curvedness (Fig.15), is introduced to understand the coordination and the chemical interactions in the two complexes $[\mathbf{A g}(\mathbf{L 1})]\left(\mathbf{N O}_{3}\right)$ and $[\mathbf{A g}$ $(\mathrm{L2})]_{\mathbf{n}}\left(\mathrm{NO}_{3}\right)_{\mathbf{n}}\left(\mathrm{H}_{2} \mathrm{O}\right)$.

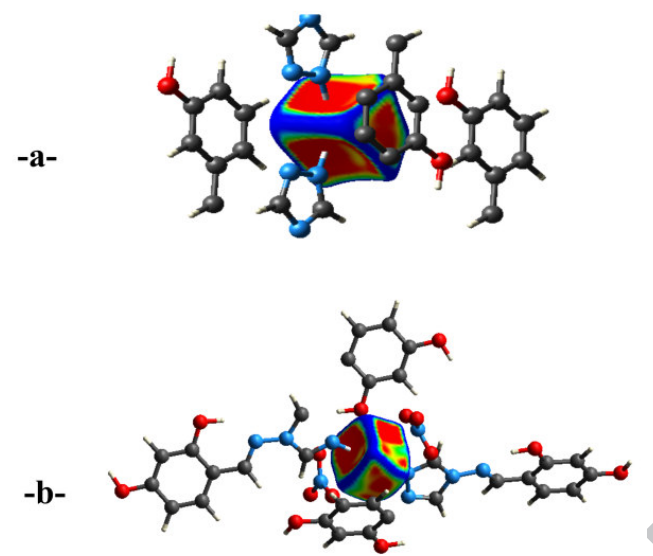

Fig.15 : Curvedness plotted on the atomic Hirshfeld surface is mapped from -1,4 (flat; red) to -0,3 (sphere-like, blue).(a): [Ag ( $\mathbf{L 1})]\left(\mathbf{N O}_{\mathbf{3}}\right)$ and (b): $[\mathbf{A g}(\mathbf{L} 2)]_{\mathbf{n}}\left(\mathbf{N O}_{\mathbf{3}}\right)_{\mathbf{n}}\left(\mathbf{H}_{\mathbf{2}} \mathbf{O}\right)$

The Hirshfeld surface was divided into a set of patches, where each patch represents a different interaction[8]. The shape of the surface indicates the regions of interactions, which varies from high curvature (blue) to low curvature (red), (Fig.15). Curvedness plotted on the Hirshfeld surface reflects closer contacts between adjacent atoms [62] and allows also to estimate the coordination number of the metal [65-66]. The flat regions on the Hirshfeld surface around $\operatorname{Ag}(\mathrm{I})$ ion in both structures $[\mathrm{Ag}(\mathbf{L 1})]\left(\mathbf{N O}_{3}\right)$ and $[\mathrm{Ag}(\mathbf{L 2})]_{\mathbf{n}}\left(\mathbf{N O}_{3}\right)_{\mathbf{n}}\left(\mathbf{H}_{\mathbf{2}} \mathbf{O}\right)$, reveal the number and the nature of the interatomic interaction. The large flat regions are related to the strong interaction [60]. These regions on the surface around $\mathrm{Ag}(\mathrm{I})$ cation in the $[\mathrm{Ag}(\mathbf{L 1})]\left(\mathrm{NO}_{3}\right)$ dimer is related to the covalent bonds $\mathrm{Ag}-\mathrm{N}$, Where the metal is tricoordinated by three nitrogens of triazole rings. The remaining small flat regions on the surface refer to the medium and weak interactions $\mathrm{Ag} \ldots \pi$ and $\mathrm{Ag} \ldots \mathrm{O}$, respectively. In the $[\mathrm{Ag}(\mathbf{L 2})]_{\mathbf{n}}\left(\mathbf{N O}_{3}\right)_{\mathbf{n}}\left(\mathbf{H}_{2} \mathbf{O}\right)$ polymer structure, the Hirshfeld surface around the $\mathrm{Ag}(\mathrm{I})$ cation shows two large flat regions related to the covalent bonds $\mathrm{Ag}-\mathrm{N}$, which refer to coordination number 2 (linear structure). Besides, the small flat regions denote medium and weak interactions $\mathrm{Ag} . . . \mathrm{O}$ and $\mathrm{Ag} \ldots \pi$, respectively. The atomic Hirshfeld volumes have been calculated for the $\operatorname{Ag}(\mathrm{I})$ cation in both structure to be $27.03 \AA^{3}$ for the dimer and $22.95 \AA^{3}$ for the polymer. Due to the coordination number of the silver in the two structures, the Hirshfeld volume of the $\operatorname{Ag}(\mathrm{I})$ cation in the dimer is a bit larger than that one of the same atom in the polymer structure. 


\section{Antibacterial studies:}

Antibacterial activity of the free ligands (L1), (L2) and of their silver complexes $[\mathbf{A g}(\mathbf{L 1})]\left(\mathbf{N O}_{3}\right)$ and $[\mathrm{Ag}(\mathbf{L 2})]_{\mathbf{n}}\left(\mathbf{N O}_{3}\right)_{\mathbf{n}}\left(\mathbf{H}_{2} \mathbf{O}\right)$ has been evaluated using the well-diffusion method [67] at $20 \mathrm{mg} \cdot \mathrm{ml}^{-1}$ concentration in DMSO against four Gram-negative (E. coli, Salmonella typhimurium, Klebsiella pneumoniae and serratia marcescens) and two Grampositive (Staphylococcus aureus, streptococcus) bacteria strains. The standard antibiotics, Colistin, Fosfomycin, Gentamycin, Erythromycin, Rifampicin, Amikacin, Ofloxacin and Amoxicillin have been used as positive controls against some of the tested bacteria. Solvent control test was also carried out to study the DMSO effect on the bacteria growth. Similarly, in an attempt to dissociate the inhibitory and antimicrobial effects of ionic silver from the one of the silver complexes described in this study, $\mathrm{AgNO}_{3}$ salt was also used as second control test. The antibacterial activity results of these compounds are listed table S4 in supplementary materials, and represented in Fig.16, as averages of four measurements.

It was observed that the DMSO alone did not inhibit the growth of these bacteria while, as expected, the silver nitrate exhibits significant antibacterial activity. Indeed, even if the precise antimicrobial mechanism of ionic silver is not totally elucidated, several plausible mechanisms have been described in the literature. It is thought that silver ions can kill bacteria by entering the cell through interactions with enzymes present on cell surface, and once inside the cell can bind sulphur-containing groups such as thiol in proteins, leading to the deactivation or the denaturation of enzymes essential for the cell metabolism [68]. Moreover, TEM imaging of bacteria exposed to silver nitrate showed phenomenon of DNA condensation, leading to the loss of its replication ability, along with deep structural damage of cell membranes [34]. Also, the antibacterial activity of silver may be due to its binding to the surface of the cell membrane disrupting the permeability and the respiration $[69,70]$.

In our experiments, the antibacterial activity of silver nitrate was especially strong against staphylococcus aureus, with a diameter of inhibition zone of 22.0(6.7) mm, significantly larger than the one of Rifampicin $(d=13 \mathrm{~mm})$, a drug used generally as an adjunctive in the treatment of staphylococcus aureus infections [71].

Experiments performed using the free ligands indicated that they do not display any measurable antibacterial activity, excepted against Serratia Marcescens for which inhibition zones of 13.8(1.7) $\mathrm{mm}$ and 9.5(1.7) mm diameters were observed for (L1) and (L2) ligands, respectively. These clearance zones diameters compare, for (L1), with the one of silver nitrate $(d=15.0(1.1) \mathrm{mm})$, but is significantly smaller in the case of (L2). Nevertheless, this is 
especially remarkable that the standard antibiotic Gentamycin did not lead to any measurable inhibition zone in the case of the Serratia strain tested in this study. Even if the precise mechanism of action of these ligands on Serratia Marcescens is unknown, the fact that they are active against a Gram-negative bacteria indicate that the lipophilicity of (L1) and (L2) molecules allows them to cross, or at least to interfere with their outer phospholipidic membrane. The outer membrane permeability barrier has indeed a big impact on the susceptibility of the microorganism to antibiotics [72-73].

Antimicrobial activity measurements were also performed to test the metal complexes described in this study. In the case of Gram-positive bacteria, Fig. 16 shows that the complexes $[\mathbf{A g}(\mathbf{L 1})]\left(\mathbf{N O}_{3}\right)$ and $[\mathrm{Ag}(\mathbf{L 2})]_{\mathbf{n}}\left(\mathbf{N O}_{3}\right)_{\mathbf{n}}\left(\mathbf{H}_{\mathbf{2}} \mathbf{O}\right)$ display clearance zones of respectively 19(1) $\mathrm{mm} / 17.3(1.3) \mathrm{mm}$ diameters for Staphylococcus aureus and 16.0(2.5) $\mathrm{mm}$ /15.0(1.1) $\mathrm{mm}$ for Steptococcus. These antimicrobial activities are however comparable to the ones obtained, under the same experimental conditions, with silver nitrate alone $(d=22(7)$ $\mathrm{mm}$ for Staphylococcus and 15.3(1.3) $\mathrm{mm}$ for Steptococcus). Hence, given that the parent ligands alone did not display any measurable activity for these bacteria strains, these results indicate that the antimicrobial effect of the $[\mathrm{Ag}(\mathbf{L 1})]\left(\mathbf{N O}_{3}\right)$ and $[\mathrm{Ag}(\mathbf{L 2})]_{\mathbf{n}}\left(\mathbf{N O}_{3}\right)_{\mathbf{n}}\left(\mathbf{H}_{2} \mathbf{O}\right)$ complexes cannot reliably be distinguished from the one of ionic silver.

Experiments performed to test the silver complexes against Gram-negative bacteria led to variable outcomes. At first, it appears for Salmonella typhimurim that the clearance zones obtained for both complexes, accounting for standard errors, compare with the one of the silver nitrate alone $\left(d=16.3(1.3) \mathrm{mm}, 15.3(1.3) \mathrm{mm}\right.$ and $16.5(8) \mathrm{mm}$ for $[\mathbf{A g}(\mathbf{L 1})]\left(\mathbf{N O}_{3}\right)$, $[\mathbf{A g}(\mathbf{L 2})]_{\mathbf{n}}\left(\mathbf{N O}_{3}\right)_{\mathbf{n}}\left(\mathbf{H}_{2} \mathbf{O}\right)$ and $\mathrm{AgNO}_{3}$, respectively, (Fig. 16), leading to inconclusive results concerning a possible antimicrobial activity of the silver complexes in this case. For Serratia Marcescens, both (L1) and (L2) ligands displayed moderate antimicrobial activities, comparable or lower than the one of silver nitrate. When these ligands are being tested in their silver complex form, diameters of inhibition zones, again, are comparable to the ones obtained with silver nitrate (Fig. 16). Besides, the most significant results were obtained for antimicrobial activities of the complexes against E. Coli and Klebsiella Pneumoniae. Indeed, for the first bacterium, E. Coli, both $\mathrm{Ag}(\mathrm{I})$ complexes exhibit more efficient antibacterial activity than $\mathrm{AgNO}_{3}(d=11.0(1.1) \mathrm{mm})$, and the polymer $[\mathbf{A g}(\mathbf{L} 2)]_{\mathbf{n}}\left(\mathbf{N O}_{3}\right)_{\mathbf{n}}\left(\mathbf{H}_{2} \mathbf{O}\right)(d=$ $17.8(1.7) \mathrm{mm})$ has a better activity than the dimer $[\mathbf{A g}(\mathbf{L 1})]\left(\mathbf{N O}_{3}\right)(d=14(0) \mathrm{mm})$. For the second bacterium, Klebsiella pneumoniae, only the polymer based on (L2) ligand exhibits a significantly better activity $(d=26.0(2.5) \mathrm{mm})$ than $\mathrm{AgNO}_{3}(d=14.5(1.8) \mathrm{mm})$. This result is especially remarkable as the isolated ligand (L2) seemed inactive against Klebsiella 
Pneumoniae, and the antibacterial activity of the corresponding complex compare with the one obtained for the standard antibiotic Gentamycin tested in the experiments $(d=29 \mathrm{~mm})$. Even if the elucidation of a precise molecular mechanism of the bactericidal effect of $[\mathbf{A g}(\mathbf{L 2})]_{\mathbf{n}}\left(\mathbf{N O}_{3}\right)_{\mathbf{n}}\left(\mathbf{H}_{2} \mathbf{O}\right)$ against Klebsiella pneumoniae is beyond the scope of this study, plausible explanations can nevertheless be proposed. At first, the lipophilicity of the ligand (L2), which has been shown able to be moderately active against the Gram-negative bacteria Serratia Marcescens, can be enhanced upon complexation with $\operatorname{Ag}(\mathrm{I})$ [74], allowing the $[\mathbf{A g}(\mathbf{L 2})]_{\mathbf{n}}\left(\mathbf{N O}_{3}\right)_{\mathbf{n}}\left(\mathbf{H}_{2} \mathbf{O}\right)$ complex to cross the phospholipidic membrane of Klebsiella pneumoniae. Once inside the cell, assuming a favourable kinetic of de-ligation reaction, and given that the ligand (L2) possesses a triazole group known to be a strong nitrogen donor toward transition metals, the chelation theory may explain the measured activity. Indeed, chelating agents are able to disturb the metal metabolism of microorganisms by interfering with metal acquisition needed for crucial reactions, or by inhibiting the biological role of metal-dependent proteins [75]. In this scenario, the observed activity of $[\mathrm{Ag}(\mathrm{L2})]_{\mathbf{n}}\left(\mathrm{NO}_{3}\right)_{\mathbf{n}}\left(\mathrm{H}_{2} \mathrm{O}\right)$ is thus interpreted as a synergetic effect of the chelating properties of the ligand (L2) and the known antimicrobial activity of ionic silver, in conjunction with an enhanced lipophilicity of the ligand upon formation of the silver complex. This may explain why the isolated (L2) ligand does not seem to be active and why the silver complex based on (L2) appears significantly more active than the silver nitrate control.

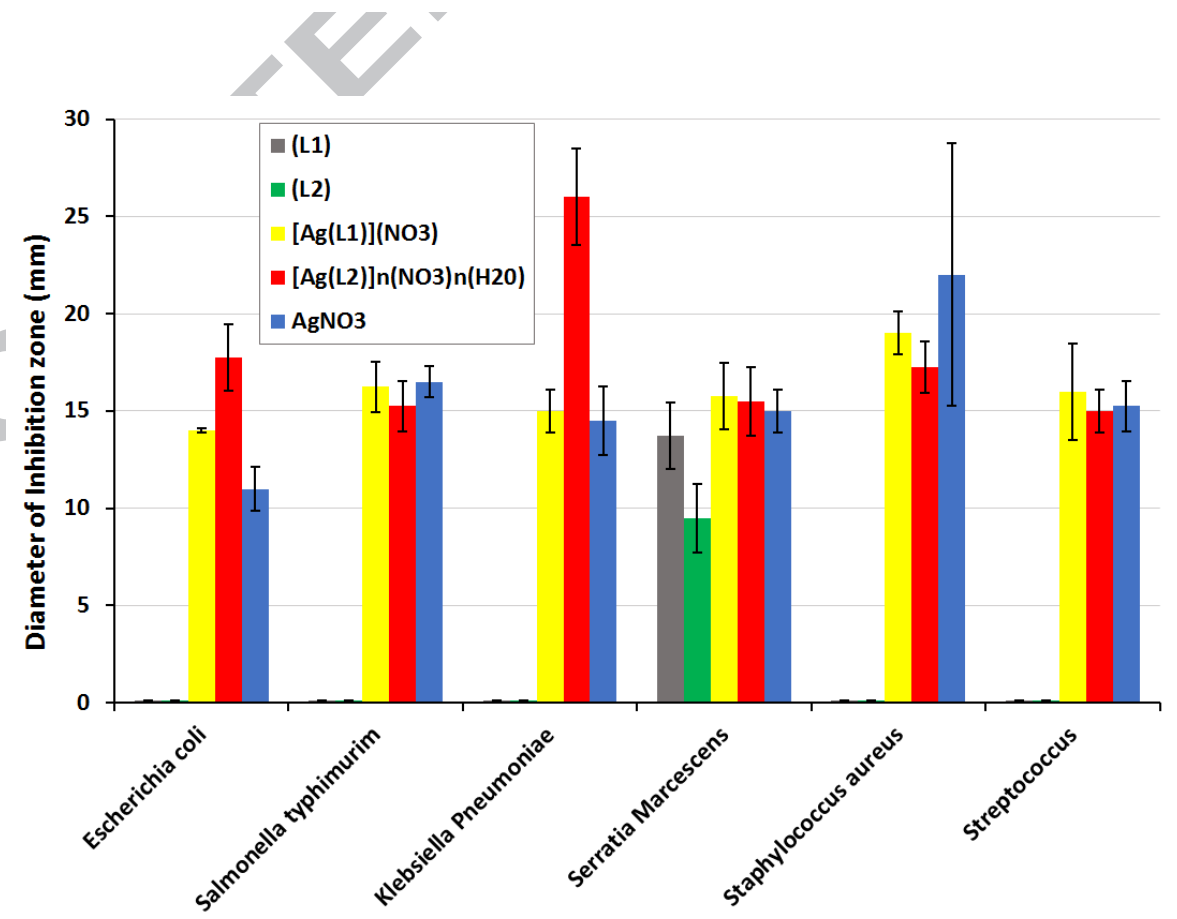


Fig.16: Antimicrobial activity of the four title compounds. Error bars correspond to $95 \%$ confidence intervals using a student $t$-distribution based on quadruplicate measurements.

\section{Conclusion:}

Two hydroxy Schiff bases have been synthesized by condensation of 4-amino-4H-1,2,4triazole with 3-hydroxybenzaldehyde for the first ligand (L1) and 2,4-dihydroxybenzaldehyde for the second one (L2). The preliminary IR spectroscopy study of these two ligands has highlighted the formation of imine bond $-\mathrm{C}=\mathrm{N}$ characteristic of Schiff base compounds (band around $1600 \mathrm{~cm}^{-1}$ ). The two compounds differ by the presence of an additional $-\mathrm{OH}$ in the second Schiff base (L2). This difference influences directly the hydrogen bond network involving the two ligands. Infinite chains formed by $\mathrm{O}-\mathrm{H} . . \mathrm{N}$ hydrogen bonds in (L1) are indeed transformed into 2D layers in (L2). Three dimensional supramolecular assemblies of (L1) and (L2) in their respective crystal structures is then ensured by C-H...N hydrogen bonds, and $\pi . . \pi$ stacking interactions.

The reaction of these two Schiff bases with $\mathrm{AgNO}_{3}$ leads to the formation of $\mathrm{Ag}(\mathrm{I})$ dimer $[\mathrm{Ag}(\mathbf{L 1})]\left(\mathbf{N O}_{3}\right)$ with $(\mathbf{L 1})$ and polymer $[\mathrm{Ag}(\mathbf{L 2})]_{\mathbf{n}}\left(\mathbf{N O}_{3}\right)_{\mathbf{n}}\left(\mathbf{H}_{2} \mathbf{O}\right)$ with $(\mathbf{L 2})$ which includes a water solvent molecule. Ag adopts a trigonal geometry in the dimer and a square pyramidal one in the polymer. This polymer expands on 1D direction and the O-H...O hydroxyl-water hydrogen bonds connect the polymeric chains in 2D sheets parallel to (bc) plane. C-H...N, C$\mathrm{H} . . \mathrm{O}$ and $\pi \ldots \pi$ stacking reinforce the crystal structure of the two compounds and ensure the three dimensionality of their networks. Analyse based on Hirshfeld surfaces confirm the presence of these interactions and reveals that $\mathrm{N}$...H and $\mathrm{O}$...H interactions evolve inversely in the way (L1), (L2), $\operatorname{Ag}(\mathbf{L 1})]\left(\mathbf{N O}_{3}\right)$ and $[\mathbf{A g}(\mathbf{L 2})]_{\mathbf{n}}\left(\mathbf{N O}_{3}\right)_{\mathbf{n}}\left(\mathbf{H}_{2} \mathbf{O}\right)$. The percentage of $\mathrm{O} \ldots \mathrm{H}$ interaction increases in this way while the one of N...H contacts decreases, and it is probably due to the presence of additional $-\mathrm{OH}$ in the second ligand (L2), and of a water molecule in the polymer $[\mathbf{A g}(\mathbf{L 2})]_{\mathbf{n}}\left(\mathbf{N O}_{3}\right)_{\mathbf{n}}\left(\mathbf{H}_{2} \mathbf{O}\right)$. Antimicrobial activity of the four compounds confirms also the importance of $\operatorname{Ag}(\mathrm{I})$ in bacteria inhibition, indeed, while the free ligands are only active for one bacterium (Serratia Marcescens), the silver (I) dimer and polymer inhibit the growth of all bacteria strains tested in this study. However, activities of the complexes are generally comparable to the ones of the silver nitrate tested alone, except in the case of the polymer $[\mathrm{Ag}(\mathbf{L 2})]_{\mathbf{n}}\left(\mathbf{N O}_{3}\right)_{\mathbf{n}}\left(\mathbf{H}_{\mathbf{2}} \mathrm{O}\right)$ which has been shown to be significantly more active than ionic silver against Klebsiella pneumoniae.

\section{Acknowledgments:}


- Institut Jean Barriol X-ray diffraction facility. Dr. E. Wenger.

- Pr. Foudil Khelifa, Director of "Laboratoire d'hygiène de la Wilaya de Constantine. Algérie" for antimicrobial facility.

- Biologists: Zine Faiza, Haifi Maya and Belhaffaf Mouni for their help.

\section{References:}

[1] Schiff, H. Ann. Chem. 1864, 131, 118-119.

[2] Barton, D. \& Ollis, W. D. 1979, Comprehensive Organic Chemistry, vol 2. Oxford:

Pergamon. [3] Ingold, C. K. 1969, Structure and Mechanism in Organic Chemistry, 2nd ed. Ithaca: Cornell University Press.

[4] Layer, R. W. Chem. Rev. 1963, 63, 489-510.

[5] Anouar, E.H.; Raweh, S.; Bayach, I.; Taha, M.; Baharudin, M.S.; Meo, F.D.; Hasan, M.H.; Adam, A.; Ismail, N.H.; Weber, J.F. J. Comput. Aided Mol. Des. 2013, 27, 951-964.

[6] Taha, M.; Ismail, N.H.; Jamil, W.; Yousuf, S.; Jaafar, F.M.; Ali, M.I.; Kashif, S.M.; Hussain, E. Molecules, 2013, 18, 10912-10929.

[7] Khan, K.M.; Shah, Z.; Ahmad, V.U.; Khan, M.; Taha, M.; Ali, S.; Perveen, S.; Choudhary, M.I.; Voelter, W. Med. Chem. 2012, 8, 452-461.

[8] Khan, K.M.; Taha, M.; Naz, F.; Ali, S.; Perveen, S.; Choudhary, M.I. Med. Chem. 2012, $8,705-710$.

[9] Aziz, A.N.; Taha, M.; Ismail, N.H.; Anouar, E.H.; Yousuf, S.; Jamil, W.; Awang, K.; Ahmat, N.; Khan, K.M. and Kashif, S.M. Molecules, 2014, 19, 8414-8433.

[10] Jain, J.S.; Srivastava, R.S.; Aggarwal, N.; Sinha, R. Med. Chem. 2007, 7, 200-204.

[11] Chinnasamy, R.P.; Sundararagan, R.; Govindaraj, S. Soc. Pharm. Edu. Res. 2010, 1, $342-347$.

[12] Pandey, A.; Dewangan, D.; Verma, S.; Mishra, A.; Dubey, R.D. Int. J. Chem. Tech. Res. 2011, 3, 178-184.

[13] Mishra, P.; Gupta, P.N.; Shakya, A.K.; Shukla, R.; Srimal, R.C. Indian J. Physiol. Pharmacol. 1995, 39, 169-172.

[14] Hasegawa, S.; Horike, S.; Matsuda, R.; Furukawa, S.; Mochizuki, K.; Kinoshita, Y.; Kitagawa, S. J. Am. Chem. Soc. 2007, 129, 2607- 2614. 
[15] Kajiwara, T.; Fujii, M.; Tsujimoto, M.; Kobayashi, K.; Higuchi, M.; Tanaka, K.; Kitagawa, S. Angew. Chem., Int. Ed. 2016, 55, 2697- 2700.

[16] Flynn, D. C.; Ramakrishna, G.; Yang, H.; Northrop, B. H.; Stang, P. J.; Goodson, T., III J. Am. Chem. Soc. 2010, 132, 1348-1358.

[17] Cui, Y.; Yue, Y.; Qian, G.; Chen, B. Chem. Rev. 2012, 112, 1126-1162.

[18] Xie, Z.; Ma, L.; de Krafft, K. E.; Jin, A.; Lin, W. J. Am. Chem. Soc. 2010, 132, 922-923.

[19] Zhang, Q.; Li, B.; Chen, L. Inorg. Chem. 2013, 52, 9356-9362.

[20] Zhang, W.; Xiong, R. Chem. Rev. 2012, 112, 1163-1195.

[21] Gygi, D.; Bloch, E. D.; Mason, J. A.; Hudson, M. R.; Gonzalez, M. I.; Siegelman, R. L.; Darwish, T. A.; Queen, W. L.; Brown, C. M.; Long, R. Chem. Mater. 2016, 28, 1128-1138. [22] Gańdara,F.;Furukawa,H.;Lee,S.;Yaghi,O.M.J.Am.Chem. Soc. 2014, 136, 5271-5274.

[23] Ma, S.; Zhou, H. Chem. Commun. 2010, 46, 44-53.

[24] Barea, E.; Montoro, C.; Navarro, J. A. R. Chem. Soc. Rev. 2014, 43, 5419-5430.

[25] Bloch, D. E.; Queen, W. L.; Krishna, R.; Zadrozny, J. M.; Brown, C. M.; Long, J. R. Science 2012, 335, 1606-1611.

[26] Ünaleroğlu and C.; Hökelek, T. Spectrosc. Lett. 2002, 35, 317

[27] Thangadurai, T. D.; Gawri, M.; Natarajan, K. Synth. React. Inorg. Met.-Org. Chem. 2002, 32, 329.

[28] Salib, K. A. R.; Stefan, S. L.; Abu El-Wafa, S. M.; El-Shafiy, H. F. Synth. React. Inorg. Met.-Org. Chem. 2001, 31, 895.

[29] Fan, Y.H.; Bi, C.F.; Li, J.Y. Synth. React. Inorg. Met.-Org. Chem. 2003, 33, 137.

[30] Serron, S.A.; Haar, C.M.; Nolan, S.P.; Brammer, L. J. Organomet. Chem. 1997, 16, 5120.

[31] Ferreira, V.F.; da Rocha, D.; da Silva, F.; Ferreira, P.G.; Boechat, N.A.; Magalhães, J.L. Expert Opinion on Therapeutic Patents, 2013, 23, 319-331.

[32] Kharb, R.; Sharma, P.C.; Yar, M.S. J. Enzyme Inhib. Med. Chem., 2011, 26, 1-21.

[33] Percival, S.L.; Bowler, P.G.; Russell, D. J Hosp Infect, 2005, 60, 1-7.

[34] Feng, Q.L.; Wu, J.; Chen, G.Q.; Cui, F.Z.; Kim, T.N.; Kim, J.O. Journal of Biomedical Materials Research Part A, 2000, 52(4), 662-668.

[35] Rai, M.; Yadav, A.; Gade, A., Biotechnology advances, 2009, 27, 76-83.

[36] Medici, S.; Peana, M.; Crisponi, G.; Nurchi, V.M.; Lachowicz, J.I.; Remelli, R.; Zoroddu, M.A. Coordination Chemistry Reviews, 2016, 349-359. 
[37] Wilkinson, G. Comprehensive Coordination Chemistry; Pergamon Press: New York, 1987.

[38] Wang, Y.; Yi, L.; Yang, X.; Ding, B.; Cheng, P.; Liao, D.-Z.; Yan, S.-P. Inorg. Chem. 2006, 45, 5822.

[39] Oxford Diffraction 2008. CrysAlis CCD and CrysAlis RED. Versions 1.171.32.21. Oxford Diffraction, Wroclaw, Poland.

[40] Sheldrick, G. M. Acta Cryst. 2015, C71, 3-8.

[41] Jelsch, C.; Ejsmont, K.; Huder, L. IUCr. 2014, 1, 119-128.

[42] Spackman, M. A. and Jayatilaka D. CrystEngComm, 2009, 11, 19.

[43] Spackman, M.A. and McKinnon, J.J. CrystEngComm. 2002, 4, 378-392

[44] Wolff, S. K.; Grimwood, D. J.; McKinnon, J. J.; Turner, M. J.; Jayatilaka, D. \& Spackman, M. A. Crystal Explorer, 2012, the University of Western Australia.

[45] Agarwal, R.K.; Prakash, B.; Kumar, V. and Khan, A.A. Journal of the Iranian Chemical Society, 2007, 4, 114-125.

[46] Mapari, A.K. and Mangaonka, K.V. International Journal of ChemTech Research, 2011, 3, 477-482.

[47] Abu-Khadra, A.S.; Farag, R.S.; Mokhtar Abdel-Hady, A.E.D. American Journal of Analytical Chemistry, 2016, 7, 233-245.

[48] (a) Matulkova, I. ; Nemec, I.; Teubner, K.; Nemec, P.; Micka, Z. Journal of molecular structure, 2008, 873, 46-60. (b) Hanif, M.; Chohan, Z. H. Spectrochimica Acta Part A:

Molecular and Biomolecular Spectroscopy, 2013, 104, 468-476.

[49] Safin, D.A.; Robeyns, K. and Garcia,Y. CrystEngComm. 2016, 18, 7284-7296.

[50] F.H. Allen, O. Kennard, D.G. Watson, L. Brammer, A.G. Orpen, R. Taylor, J. Chem. Soc. Perkin Trans. 1987, 2, 1-19.

[51] Kwiecien, A., Barys, M. and Ciunik, Z. molecules, 2014, 19, 11160-11177.

[52] Wajda-Hermanowicz, K.; Pieniazczak, D.; Zatajska, A.; Wrobel, R.; Drabent, K. and Ciunik, Z. molecules, 2015, 20, 17109- 17131.

[53] Etter, M. C. Acc. Chem. Res. 1990, 23, 120-126.

[54] Bernstein, J.; Davis, R. E.; Shimoni, L. and Chang, N. L. Angew. Chem. Int. Ed. Engl. 1995, 34, 1555-1573.

[55] (a) Labisbal, E.; Rodriguez, L.; Vizoso, A.; Alonso, M.; Romero, J.; Garcia-Vazquez, J.A.; Sousa-Pedrares, A. and Sousa, A. Z. Anorg. Allg. Chem. 2005, 631, 2107-2114 
(b) Cinarli, A.; Gurbuz, D.; Tavman, A.; Birteksoz, A.S. Chin. J. Chem. 2012, 30, 449-459

(c) Zhang, Y.; Chen, S.; Fan, G.; Zhao, Z.; Gao, S. Chin. J. Chem., 2009, 27, 1697-1702

(d) Yu, H.-X.; Ma, J.-F.; Xu, G.-H.; Li, S.-L.; Yang, J.; Liu, Y.-Y. and Chen, Y.-X. Journal of Organometallic Chemistry, 2006, 691, 3531-3539

[56] (a) Kennedy, A.R.; Brown, K.G.; Graham, D.; Kirkhouse, J.B.; Kittner, M.; Major, C.; McHugh, C.J.; Murdoc, P. and Smith, W.E. New J. Chem. 2005, 29, 826; (b) Catalano, V.J.; Malwitz, M.A.; Etogo, A.O. Inorg. Chem. 2004, 43, 5714; (c) Zheng, Y.; Li, J.R.; Du, M.; Zou, R.Q.; Bu, X.H. Cryst. Growth Des. 2005, 5, 215.

[57] Sang, R.L. and Xu, L. Eur. J. Inorg. Chem. 2006, 1260.

[58] Wilkinson, G. Comprehensive Coordination Chemistry; Pergamon Press: New York, 1987. (b) Wang, Y.; Yi, L.; Yang, X.; Ding, B.; Cheng, P.; Liao, D.-Z.; Yan, S.-P. Inorg. Chem. 2006, 45, 5822-5829.

[59] Wang, Y.; Ding, B.; Cheng, P, Liao, D.-Z.; and Yan, S.-P. Inorg. Chem. 2007, 46, $2002-$ 2010.

[60] (a) Deng, Z.-P.; Zhu, L.-N.; Gao, S.; Huo, L.-H, and Weng Ng, S. Crystal Growth \& Design. 2008, Vol. 8, No. 9, 3277-3284 ; (b) Medishetty, R.; Sahoo, S.C.; Mulijanto, C.E.; Naumov, P. and Jagadese J. Vittal Chem. Mater. 2015, 27, 1821-1829.

[61] Nbili, W.; Kaabi, K.; Ferenc, W.; Cristovao, B.; Lefebvre, F.; Jelsch, C.; Ben Nasr, C. J. mol.struct. 2017, 1130, 114-121.

[62] Gavezzotti, A.; Filippini, G. J. Phys. Chem. 1994, 98, 4831-4837.

[63] Macrae, C. F.; Bruno, I. J.; Chisholm, J. A.; Edgington, P. R.; McCabe, P.; Pidcock, E.; Rodriguez-Monge, L.; Taylor, R.; van de Streek J.; and Wood, P. A.; J. Appl. Cryst., 2008, 41, 466-470,

[64] Nouri, K.; Jemmali, M.; Walha, S.; Zehani, K.; Ben Salah, A. and Bessais, L. Journal of Alloys and Compounds, 2016, doi: 10.1016/j.jallcom.2016.02.142.

[65] Skovsen, I.; Christensen, M.; Clausen, H.F.; Overgaard, J.; Stiewe, C.; Desgupta, T.; Mueller, E.; Spackman, M.A.; Iversen, B.B. Inorg. Chem. 2010, 49, 9343-9348.

[66] Smol'yakov, A.F.; Korlyukov, A.A.; Dolgushin, F.M.; Balagurova, E.V.; Chizhevsky, I.T.; Vologzhanina, A.V. Eur. J. Inorg. Chem. 2015, 5847-5855.

[67] (a) Heatley, N.G. Biochem. J. 1944, 38, 61-65; (b) CLSI, Performance standards for antimicrobial disk susceptibility tests, approved standards, $7^{\text {th }}$ ed., CLSI document M02-A11. Clinical and laboratory standards institute, 950 west valley road, suite 2500, Wayne, Pennsylvania 19087, USA, 2012.

[68] Li, X.; Gong, Y.; Zhao, H. and Wang, R. Inorg. Chem., 2014, 53 (22), 12127-12134. 
[69] Pandian, S.R.K.; Deepak, V.; Kalishwaralal, K.; Viswanathan, P. and Gurunathan, S. Brazilian Journal of Microbiology, 2010, 41, 805-809.

[70] Marchetti, F.; Palmucci, J.; Pettinari, C.; Pettinari, R.; Scuri, S.; Grappasonni, I.; Cocchioni, M.; Amati, M.; Lelj, F. and Crispini, A. Inorg. Chem. 2016, 55, 5453-5466.

[71] Perlroth, J.; Kuo, M.; Tan, J.; Bayer, A.S.; Miller, L.G. Arch Intern Med. 2008, 168(8), 805-819.

[72] Shraf, M. A.; Mahmood, K.; Wajid, A. IPCBEE, 2011, 10, 1-7.

[73] Castro, M.E.; Percino, M.J.; Cerón, M.; Soriano, G. and Chapela, M.V. Int. J. Electrochem. Sci. 2014, 9, 7890-7903.

[74] Haque, R.A.; Choo, S.Y.; Budagumpi, S.; Iqbal, M.A.; Al-Ashraf Abdullah, A. Eur. J. Med. Chem. 2015, 90, 82-92.

[75] Santos, A.L.; Sodre, C.L.; Valle, R.S.; Silva, B.A.; Abi-Chacra, E.A.; Silva, L.V.; SouzaGoncalves, A.L.; Sangenito, L.S.; Goncalves, D.S.; Souza, L.O.; Palmeira, V.F.; d'AvilaLevy, C.M.; Kneipp, L.F.; Kellett, A.; McCann, M.; Branquinha, M.H. Curr Med Chem., 2012, 19(17), 2715-2737. 


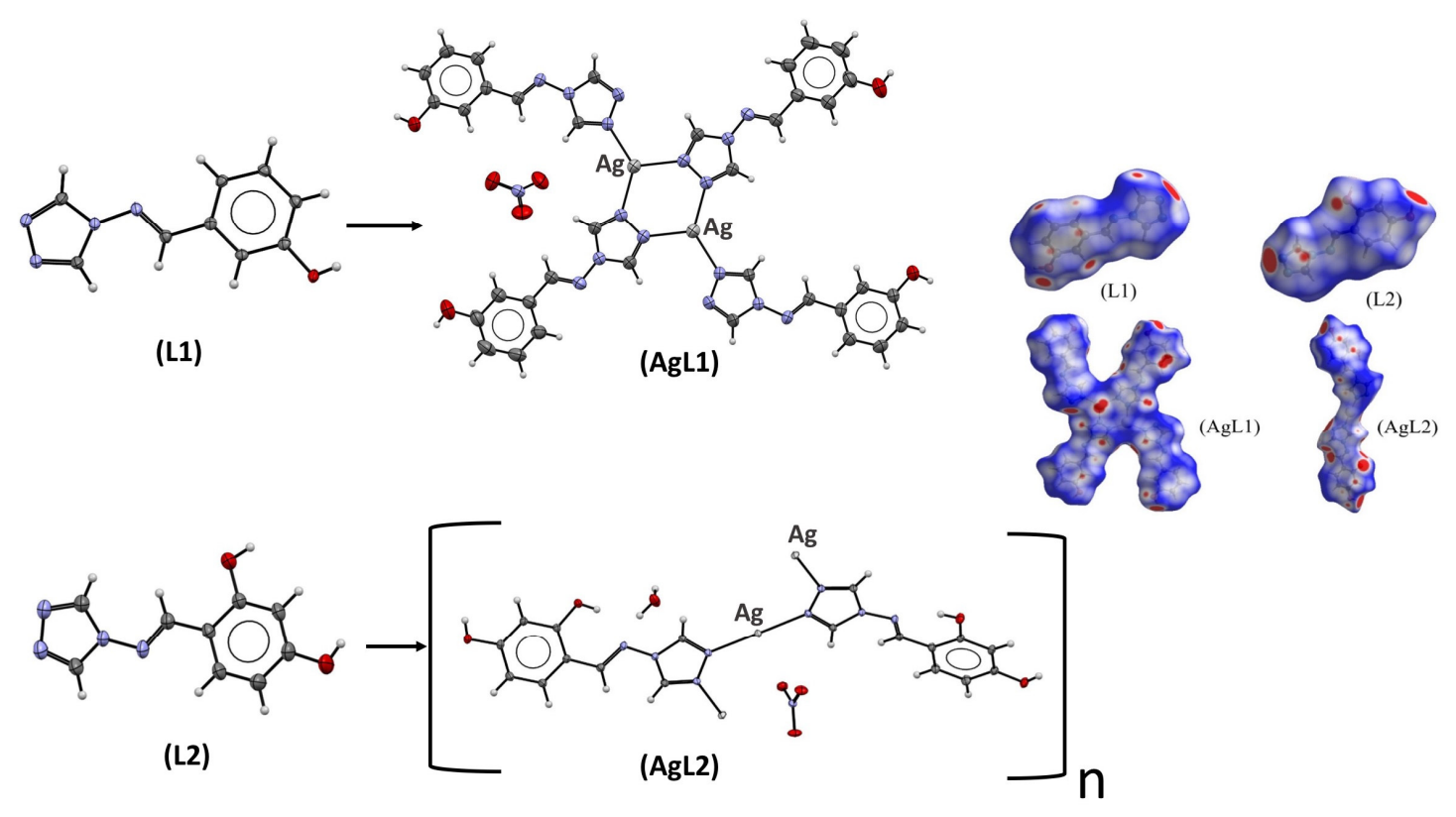




\section{Highlights}

- Synthesis of new triazole Schiff bases and their silver complexes.

- X-ray crystal structure and Hirshfield surfaces.

- Spectroscopy properties of prepared compounds.

- Antimicrobial activity 